\title{
Practical Consequences of Textual Divergences: From the Cracow Ms to Jan Łaski's Statutes
}

The analysis in Chapter 2 has shown that the Silesian-Małopolska compilation of the Magdeburg Weichbild kept evolving during its circulation in Poland. All the evidence indicates that that the process originated with a conjectural German-language archetype which was markedly different from the vulgate Weichbild that circulated in Germany. The next stage came with the translation of the Weichbild into Latin. However, a close analysis of the Latin manuscripts has revealed that the divergences in the Latin texts form patterns that persisted throughout the Weichbild's history. The only plausible explanation of this phenomenon is that initially there were two Latin translations of the Weichbild and that the Sandomierz version was a catalyst for the creation of yet another text, the Cracow version.

This chapter looks at the Magdeburg Weichbild in the final stage of its career - the authorized version published in Jan Łaski's Stutues in 1506 - which builds on both the Sandomierz version and the Cracow version.

\section{The Weichbild in Jan Łaski's Statutes}

\subsection{Formal Characteristics}

An analysis of the formal characteristics of the Weichbild in Jan Łaski's Statutes shows that it contains provisions that can be traced both to the versio Sandomiriensis and the Cracow version (see Tables 8 and 9 in Chapter 2). The former includes supplements introduced by Konrad of Sandomierz into Articles 24 and 76 as well as a provision originally transposed to Article 24 which, in the Cracow version, was additionally placed in a slot where it matches the German text. ${ }^{1}$ Furthermore, Łaski's edition includes provisions from the Constitution of Courts, which in its complete form can only be found in the Cracow version. However, the sequence of the provisions corresponds to the order of the versio Sandomiriensis, including the placement of Articles 6o and 61 about the gerada and the hergewet. The Statutes also follows Konrad of

1 Article 86 of the Statutes or Article 76 according to the numbering scheme of the Cracow BJ 169 . 
Sandomierz's design by rearranging some contents for the sake of thematic consistency - for example, the provision about horse theft in Article 69 can also be found after Article 38, which is concerned with theft.

\subsection{Sources of the Weichbild in the Statutes}

An analysis of the data in Appendix 2 indicates that the Weichbild in the Statutes is indebted both to the versio Sandomiriensis and the Cracow version.

The text of the Statutes differs from the Gniezno Ms in 68 records. In 12 cases, a new variant is introduced, ${ }^{2}$ although it is usually a collation of available variants. ${ }^{3}$ In effect, divergences from the Gniezno Ms in the Statutes and other texts actually appear in 56 records. The Commune incliti shares the greatest number of similarities with the Żagań Ms. Divergences between these two texts are exceptional; they occur in a few records only. ${ }^{4}$ In the remaining 152 records, the Statutes text conforms to MS Gn. In as many as 132 cases, there are, however, individual divergences from the Gniezno MS in one manuscript or

TABLE 19 Characteristics of the Weichbild in Jan Łaski's Statutes as compared to the Gniezno Ms (Gn.)

\section{Characteristic Number Notes \\ feature}

\begin{tabular}{|c|c|c|}
\hline $\begin{array}{l}\text { Divergence from } \\
\text { Ms Gn. }\end{array}$ & 7 & individual variants \\
\hline $\begin{array}{l}\text { Divergence from } \\
\text { Ms Gn. }\end{array}$ & 6 & $\begin{array}{l}\text { individual variation resulting from collation of different } \\
\text { texts }\end{array}$ \\
\hline $\begin{array}{l}\text { Divergence from } \\
\text { Ms Gn. }\end{array}$ & 55 & matching other texts, especially Żagań Ms (II Q 4) \\
\hline $\begin{array}{l}\text { Conformity to } \\
\text { Ms Gn. }\end{array}$ & 20 & $\begin{array}{l}\text { variations from Ms Gn. characteristic of the Cracow } \\
\text { version }\end{array}$ \\
\hline $\begin{array}{l}\text { Conformity to } \\
\text { MS Gn. }\end{array}$ & 132 & $\begin{array}{l}\text { records indicating individual variants or variations } \\
\text { characteristic for groups of other texts }\end{array}$ \\
\hline
\end{tabular}

2 No. 16, 35, 45, 75, 77, 81, 83, 111 139, 159, 16o, 211, and 213. Conformity only with MS BN 3068 (No. 12 and 17), or only with MS BOZ and MS 951b (No. 112); it is not clear if they were added into the Statutes later, or whether they were part of it originally and adapted later into other texts. мS вN 3068 , мS воZ, and мS 951b come from the beginning of the 16th century.

3 No. $16,35,45,81,83$, and 213 .

4 No. $12,17,89,90$, and 112. Cf. note 2. 
divergences that are peculiar to a group of manuscripts. ${ }^{5}$ A remaining set of 20 records belongs to a different category. There, the text of the Statutes conforms to the Gniezno ms, although the records are characteristic of the Cracow version. ${ }^{6}$ While the Cracow version of the Weichbild in Statutes comes from a text close to Żagań Ms (though not identical to it), the versio Sandomiriensis depends in a similar way on the Żegota Pauli's ms or another manuscript like it. Only in the Żegota Pauli's ms, the Statutes, Pleszew ms, and Przemyśl ms do we find the qualification concerning household goods heritable by the deceased's widow - they include such goods 'in possession of her husband at the time of his death. ${ }^{7}$ It is certainly more probable that Łaski adopted that explanation from a manuscript associated with Cracow (i.e. the Żegota Pauli's Ms) than from Przemyśl or from Pleszew.

The data from Appendix 2 can be complemented with a comprehensive comparison of the text of the Statutes with the matching passages in the manuscripts of the Sandomierz and the Cracow versions. Table 20 lists a number of cases which illustrate the adaptation of the latter by the author of the Commune incliti.

The wording of Article 16 is a blend of the Sandomierz and the Cracow versions, produced without any significant changes in meaning. Article 19 is similar compilation: the wording of the provision is practically identical in the Żegota Pauli's and the Baworowscy manuscripts. However, the text of Article 50 in the Statues is thoroughly revised. The addition of a passage from the Żegota Pauli Ms's and the substitution of agnatus with cognatus show that at this point, the Statutes relies on the Sandomierz version (abridged). The text of Article 66, on the other hand, demonstrates exclusive reliance on the Cracow version.

The use by the Statutes of the texts of the two versions is presented in Table 21. The versio Sandomiriensis is represented here by the Gniezno MS and the Żegota Pauli's ms, while the Cracow version is represented by the Baworowscy Ms and the Żagań Ms. ${ }^{8}$

Table 21 indicates that 51 per cent of the provisions of the Weichbild in Commune incliti come exclusively from the Cracow version. If those articles whose text depends on both versions are counted, the dependence of Łaski's Weichbild on the Cracow version rises to 65 per cent. In sum, the dominant position of the Cracow version for Jan Laski and his collaborators

5 For example Ms BN 12607/Oss., MS AJG/Kiel., or the Wawel variant of ms Dział. IV/Warsz.

6 No. 1, 15, 22, 28, 52, 62, 65, 79, 88, 91, 93, 110, 130, 135, 166, 169, 170, 195, 197, and 220.

7 No. 64.

8 The Weichbild in the Statutes has many similarities with the text of the Żagań ms, but the latter also has many peculiarities of its own. For that reason, the comparison also includes another text of the Cracow version: the Baworowscy Ms. 
TABLE 20 Examples of the use and adaptation of provisions from the versio Sandomiriensis and the Cracow version in Łaski's Statutes

Article versio Sandomiriensis

No. foll. (Żegota Pauli's MS

MS Gn. BJ 4405) versio Cracoviensis

(Żagań MS II Q 4)
Łaski's Statutes

\section{[16] +}

Part I Quid masculus dat sub banno, si possidebit pacifice et quiete absque arrestacione aliqua anno et die, hoc propius et melius optimere potest cum iudice et scabinis, quam ab ipso aliquis possit exbrigare.

[19] =

Quitquit masculus dat in iudicio banito coram iudice et scabinis, ibi recipiens dat unum solidum pro doni cognicione, quem recipiunt scabini.

[50] +

Cum moritur vir, qui pueros habuerit, qui ad annos discrecionis nondum pervenerunt, proximus agnatus debet ipsorum esse tutor, usque ad annos pubertatis pervenerint. Et si idem nondum adhuc annos pubertatis attingerit, adiutor suus esse debet proximus agnatus, usque ipse ad annos pervenerit discrecionis, et racionem
$+$

Quidquid vir dederit in iudicio sub bannito et si possessor hoc possidebit pacifice absque ullius contradicione anno et die, hoc propius et melius possessor obtinere potest cum iudice et scabinis, quam aliquis possidere seu alienare.

$=$

Quidquid masculus dat in iudicio bannito coram iudice [et] scabinis, ibi recipiens dat unum solidum pro doni cognicione, quem recipiunt scabini.

$-$

Cum moritur vir, qui pueros habuerit, qui ad annos discrecionis non dum pervenerunt, proximus cognatus eorum debet esse eorum tutor, quousque ad annos pervenerint pubertatis. Et si idem nondum ad huc pubertatis annos attingerit, adiutor suus debet propior cognatus tenetur.

suus esse, quousque ad annos pervenerint discrecionis, et racionem
Significant amendation: NO Quicquit vir dederit sub iudicio bannito et si possessor hoc possidebit pacifice et quiete absque arrestacione et condictione aliqua anno et die, hoc propius et melius obtimere potest cum iudice et scabinis, quam aliquis ab ipso possit exbrigare seu alienare. Significant amendation: NO Quitquid masculus dat in iudicio bannito coram iudice et scabinis, ibi recipiens dat unum solidum pro doni recognicione, quem recipiunt scabini pro se. Significant amendation: YES Cum moriturvir, qui pueros habuerit, qui ad annos discretionis nondum pervenerunt, proximus agnatus debet ipsorum esse tutor quousque ad annos pubertatis et discretionis pervenerint et racionem de anno ad annum de bonis pupillorum facere debet vel 
TABLE 20 Examples of the use and adaptation of provisions (cont.)

Article versio Sandomiriensis

No. foll. (Żegota Pauli's MS

MS Gn. BJ 4405) versio Cracoviensis

Łaski's Statutes

(Żagań MS II Q 4)

de anno in annum de bonis de anno ad annum de

pupillorum coram vero

ipsorum tutore facere

tenetur.

[66]

Quod si hereditas
mortaliola $[s]$ absque
heredibus inventa seu
reperta fuerit, regie cedet
maiestati.

\section{bonis pupillorum coram vero ipsorum tutore facere tenetur quidquid factus fuerit cum hiis bonis.}

$+$

\section{Quod hereditas obmortaliola, Si hereditas absque} ita quod nullus se trahat ad eadem infra annum et die, hoc pertinet ad regiam maiestatem.
Significant amendation: YES successoribus relinquitur, ita quod nullus se trahat ad eadem infra annum et die, hoc pertinet ad regiam maiestatem.

Words and phrases that are taken over verbatim by the Statutes are set in roman; words and phrases in bold indicate divergences. + indicates the presence in the Statutes of the text characteristic of that version; - indicates the absence in the Statutes of the text characteristic of either version; = indicates that the text of both versions may have been used.

TABLE 21 The origin of provisions and various significant amendations in Łaski's Statutes

\begin{tabular}{|c|c|c|c|c|c|c|c|c|c|}
\hline \multicolumn{2}{|c|}{ Article } & \multicolumn{3}{|c|}{ Characteristic features } & \multicolumn{2}{|c|}{ Article } & \multicolumn{3}{|c|}{ Characteristic features } \\
\hline $\begin{array}{l}\text { MS } \\
\text { Gn. }\end{array}$ & Statutes & v. Sand. & v. Crac. & New & $\begin{array}{l}\text { MS } \\
\text { Gn. }\end{array}$ & Statutes & v. Sand. & v. Crac. & New \\
\hline 1 & 1 & + & + & Yes & $5^{6}$ & 62 & + & - & Yes \\
\hline 2 & 2 & $=$ & $=$ & Yes & 57 & 63 & + & missing & Yes \\
\hline 3 & 3 & - & + & Yes & $5^{8}$ & 64 & $=$ & + & Yes \\
\hline 4 & 4 & + & - & Yes & 59 & 65 & + & - & Yes \\
\hline 5 & 5 & + & - & Yes & $6 o$ & 66 & - & + & Yes \\
\hline 6 & 6 & + & + & Yes & 61 & $67-68$ & - & + & Yes \\
\hline 7 & 7 & + & + & Yes & 62 & 69 & - & + & Yes \\
\hline 8 & 8 & + & - & No & 63 & 70 & - & + & Yes \\
\hline 9 & 9 & + & + & Yes & 64 & 71 & - & + & No \\
\hline 10 & 10 & - & + & Yes & 65 & 72 & - & + & Yes \\
\hline 11 & 11 & $=$ & $=$ & Yes & 66 & 73 & - & + & Yes \\
\hline
\end{tabular}


TABLE 21 The origin of provisions and various significant amendations (cont.)

\begin{tabular}{llll}
\hline Article & Characteristic features & Article
\end{tabular}

MS Statutes v. Sand. v. Crac. New

MS Statutes v. Sand. v. Crac. New Gn.

Gn.

\begin{tabular}{|c|c|c|c|c|c|c|c|c|c|}
\hline 12 & 12 & $=$ & $=$ & Yes & 67 & 74 & - & + & No \\
\hline 13 & 13 & $=$ & + & No & 68 & 75 & - & + & No \\
\hline 14 & $14-15$ & + & + & Yes & 69 & 45 & + & - & Yes \\
\hline 15 & 16 & + & - & Yes & 70 & 76 & + & - & Yes \\
\hline 16 & $17-18$ & + & + & No & 71 & 77 & - & + & Yes \\
\hline 17 & 19 & - & + & No & 72 & 78 & - & + & Yes \\
\hline 18 & $20-21$ & - & + & Yes & 73 & 79 & - & + & Yes \\
\hline 19 & 22 & $=$ & $=$ & No & 74 & 80 & - & + & No \\
\hline 20 & 23 & + & - & Yes & 75 & 81 & + & - & Yes \\
\hline 21 & 24 & + & - & Yes & 76 & 82,84 & + & + & Yes \\
\hline 22 & 25 & + & - & No & 77 & 83 & + & missing & Yes \\
\hline 23 & $26-27$ & + & + & Yes & 78 & 85 & - & + & Yes \\
\hline 24 & $28-30$ & - & + & No & - & 86 & missing & + & Yes \\
\hline 25 & 31 & + & - & Yes & 79 & 87 & - & + & Yes \\
\hline 26 & 32 & + & - & No & 80 & 88 & - & + & Yes \\
\hline 27 & 33 & $=$ & $=$ & No & 81 & 89 & - & + & Yes \\
\hline 28 & 34 & + & - & Yes & 82 & 90 & - & + & Yes \\
\hline 29 & 35 & + & - & No & 83 & 91 & - & + & Yes \\
\hline 30 & 36 & + & - & No & 84 & 92 & - & + & Yes \\
\hline 31 & 37 & + & - & No & 85 & 93 & - & + & Yes \\
\hline 32 & 38 & - & + & Yes & 86 & 94 & - & + & Yes \\
\hline 33 & 39 & - & + & Yes & 87 & $95^{-96}$ & + & - & Yes \\
\hline 34 & 40 & + & - & Yes & 88 & 97 & - & + & Yes \\
\hline 35 & 41 & - & + & No & 89 & 98 & - & + & No \\
\hline 36 & 42 & + & - & Yes & 90 & 99 & - & + & Yes \\
\hline 37 & 43 & - & + & Yes & 91 & 100 & + & + & Yes \\
\hline 38 & 44 & + & - & Yes & 92 & 101 & - & + & No \\
\hline 39 & 46 & + & + & Yes & 93 & 102 & - & + & Yes \\
\hline 40 & 47 & + & + & Yes & 94 & 103 & + & - & Yes \\
\hline 41 & 48 & $=$ & $=$ & Yes & 95 & $104-105$ & - & + & Yes \\
\hline 42 & 49 & + & + & Yes & 96 & $107-108$ & + & + & Yes \\
\hline 43 & 49 & $=$ & $=$ & Yes & 97 & 106 & - & + & Yes \\
\hline 44 & $5^{\circ}$ & $=$ & $=$ & No & 98 & 109 & - & + & Yes \\
\hline 45 & $5^{1}$ & + & - & Yes & 99 & 110 & + & + & Yes \\
\hline 46 & $5^{2}$ & + & - & Yes & 100 & 111 & + & + & Yes \\
\hline 47 & 53 & - & + & No & 101 & 112 & + & + & Yes \\
\hline 48 & 54 & $=$ & + & Yes & 102 & 114 & - & + & No \\
\hline 49 & 55 & + & - & Yes & 103 & 113 & + & + & Yes \\
\hline $5^{\circ}$ & 56 & + & - & Yes & 104 & 115 & - & + & Yes \\
\hline $5^{1}$ & 57 & + & - & Yes & 105 & 116 & - & + & No \\
\hline
\end{tabular}


TABLE 21 The origin of provisions and various significant amendations (cont.)

\begin{tabular}{|c|c|c|c|c|c|c|c|c|c|}
\hline \multicolumn{2}{|c|}{ Article } & \multicolumn{3}{|c|}{ Characteristic features } & \multicolumn{2}{|c|}{ Article } & \multicolumn{3}{|c|}{ Characteristic features } \\
\hline $\begin{array}{l}\text { MS } \\
\text { Gn. }\end{array}$ & Statutes & v. Sand. & v. Crac. & New & $\begin{array}{l}\text { MS } \\
\text { Gn. }\end{array}$ & Statutes & v. Sand. & v. Crac. & New \\
\hline $5^{2}$ & $5^{8}$ & + & - & Yes & 106 & 117 & + & - & Yes \\
\hline 53 & 59 & - & + & Yes & 107 & 118 & - & + & No \\
\hline 54 & $6 o$ & + & + & Yes & 108 & 119 & - & + & Yes \\
\hline 55 & 61 & + & missing & Yes & 109 & 119 & - & + & Yes \\
\hline
\end{tabular}

+ indicates the presence in the Statutes of the text characteristic of that version; - indicates the absence in the Statutes of the text characteristic of either version; = indicates that the text of both versions may have been used. Yes - significant amendations in the text of the Statutes; No - lack of significant amendations in the text of the Statutes; $\mathrm{U}$ - addition characteristic of the Cracow version

is unquestionable. The share of the texts of the Sandomierz version and the Cracow version in Łaski's Weichbild is presented in Figure 3, below.

The text of approximately 80 per cent of the provisions in the Statues has been revised. The revised text:

- includes all the extensions of the Cracow version that result from the addition of the ortyle and some other supplementary materials; ${ }^{9}$

- retains passages from the versio Sandomiriensis that are missing from the Cracow version; ${ }^{10}$

- fills the gaps and cleans up the corruptions by collation with the German text; ${ }^{11}$

- conforms to the versio Sandomiriensis in the consistent use of the term agnatus $^{12}$ and retains the definition of agnatic and cognatic kinship from that version; ${ }^{3}$

- infrequently introduces its own solutions by fusing the two versions of the Weichbild;

9 The following contents are missing from the Statutes: the definition of a public holiday (No. 15); the mention of the beneficiary of the goods and chattels in the possession of the deceased husband (No. 65); the procedure of proving kinship (No. 130); a supplement saying that if a suit is brought against a servant it has to be backed by an oath (No. 197).

10 No. 1, 22, 28, 52, 62, 91, 93, 135, 169, 170, 195, and 220. Following the Żagań Ms, there is an (exceptional) omission of an explanation of the negative consequences of a delay in lodging a complaint by a man who has been wounded (No. 33).

11 No. 3, 10, 60, 102, 175, 206, and 216.

12 No. $79,88,110$, and 141.

13 No. 166. 


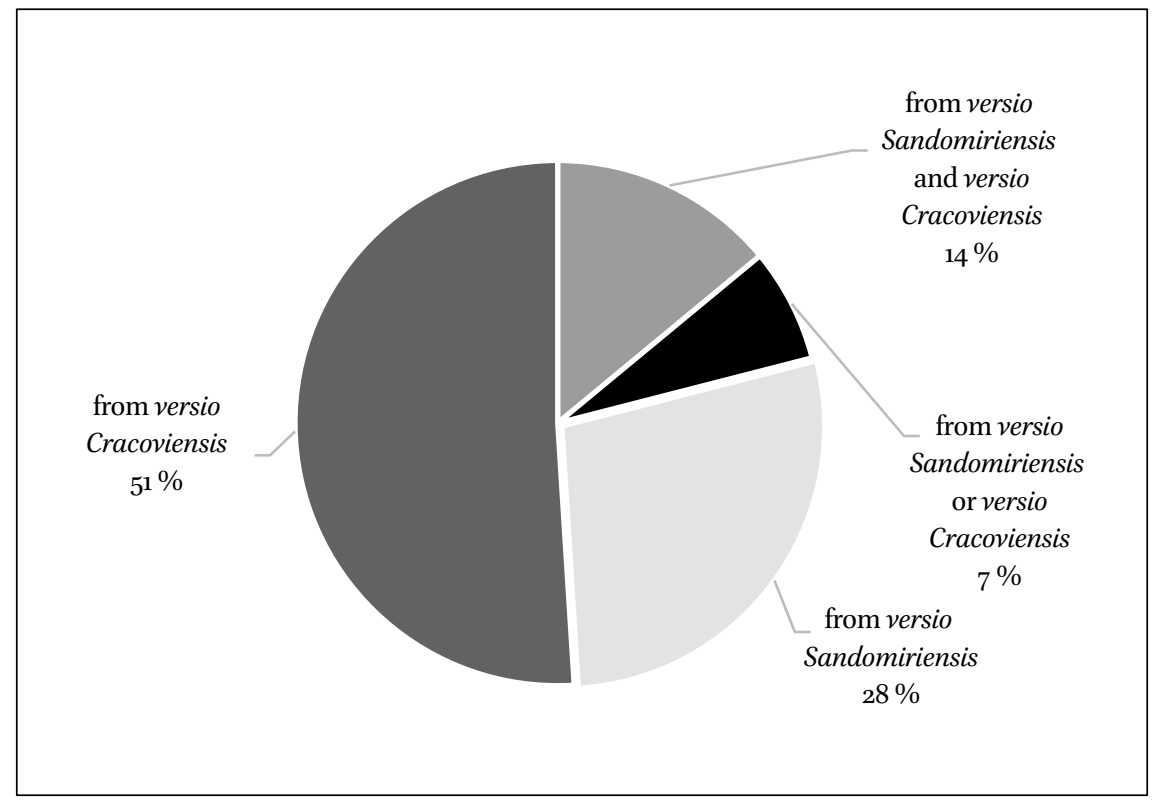

FIGURE 3 Share of the Sandomierz version and the Cracow version in the Weichbild of Commune incliti

- introduces amendations that take into account the Chełmno Law; ${ }^{14}$ and

- introduces lexical corrections in the core text of the Weichbild ${ }^{15}$ as well as in the passages taken over from the ortyle. ${ }^{16}$

\subsection{Summary: The Statutes - Culmination of the Medieval Evolution of a Legal Text}

The author of the Weichbild of the Commune incliti combined some characteristic elements of both versions of that key text that had been in use in Poland, namely, the supplements, occasional modifications of the basic texts, and careful lexical redaction. There is, however, almost no evidence that he consulted the original German text. ${ }^{17}$

\footnotetext{
14 No. 17, 18, 29, 139.

15 No. 77.

16 No. 163.

17 Similarly unfounded is the claim made by Stanisław Estreicher that Jan Łaski augmented his Statutes with excerpts from the Chełmno Law (Stanisław Estreicher, "Freimarkt and Frymark", Czasopismo Prawniczne i Ekonomiczne 25 (1929), 342). This problem is discussed by Zygfryd Rymaszewski in Eacińskie teksty Landrechtu Zwierciadta Saskiego w Polsce. Versio Vratislaviensis, versio Sandomiriensis, Laski [Latin Texts of the Landrecht of
} 
Those findings contrast with Zygfryd Rymaszewski's conclusions about the Sachsenspiegel. In collating the latter, Jan Łaski and his team of collaborators tended to reach out beyond the familiar sources and amend the text in a more decisive manner. ${ }^{18}$ The Sachsenspiegel may well have been in need of more 'aggressive' editing than the Weichbild. ${ }^{19}$ Originally a code of Saxon common law, although with notable input of regulations of a different kind, ${ }^{20}$ it was subject to more intrusive adaptation for the needs of the burghers of the Kingdom of Poland than the Ius municipale Magdeburgense. The order in which the two appear in the Statutes (i.e. Book I: The Weichbild and Book II: The Sachsenspiegel) follows their customary sequence in the manuscripts of the Cracow version. It can also be interpreted that the editors regarded the Weichbild, albeit shorter than the other law book, as a source of higher rank. This plausibility of this claim can be tested by comparing the number of references in the Weichbild gloss of the Statutes to the provisions (legal acts) in other parts of the Commune incliti and the references pointing in the other direction. The Weichbild gloss contains only one reference to the Sachsenspiegel itself,, 11 four to the Statutes of Kazimierz the Great, ${ }^{22}$ five to the Statutes of Warta $(1423),{ }^{23}$ one to the Parliament Statutes (Konstytucje Sejmu) of $1496,{ }^{24}$ one to

the Sachsenspiegel in Poland: Versio Vratislaviensis, versio Sandomiriensis, Łaski] (Łódź, 1975), p. 149.

18 Rymaszewski, Lacińskie teksty Landrechtu Zwierciadła Saskiego w Polsce. Versio, pp. 213-214.

19 Ibid., p. 213.

20 For the latest monographic study of the Sachsenspiegel, see Heiner Lück, Der Sachsenspiegel: Das berühmteste deutsche Rechtsbuch des Mittelalters (Darmstadt, 2017). Cf. also Józef Matuszewski, Artykuty stowiańskie Zwierciadta saskiego [Slavic Articles of the Sachsenspiegel], Czasopismo Prawno-Historyczne, 1 (1948), 25-74. It includes the following statement: "The Sachsenspiegel, a monument of the German law, contains also important insights into Slavic legal customs. They are all the more precious as other sources from that period pass over a number of issues that are mentioned here" (ibid., p. 70 ).

21 Reference to the provision about the dates of court sessions in Article 4.

22 Reference to the competences of a kasztelan in Article 5 dealing with the judicial procedure in cases of assault and house-breaking; in Article 12, reference to a provision concerning homicide in the Statutes; reference in Article 14 concerning the material situation of a widow; reference to a judge's appeal from Article 22 concerning a complaint against a judge who was accused of issuing an unjustified verdict (nagana).

23 Reference to the provision about price-fixing in Articles 3 and 1 (incorrect number of the folio referred to); reference from Article 11 concerning assault and house-breaking to a provision about the competences of the captain (capitaneus, starosta); reference to the article concerning the material situation of a widow from Article 14 on the same subject; reference to the provision concerning guardianship in Article 5 o.

24 Reference from Article 11 concerning assault and house-breaking to a provision about the competences of the captain (capitaneus, starosta). Cf. Wacław Uruszczak, Stanisław 
Pope Gregory XI' s bull Articuli reprobati (a condemnation of some articles of the Sachsenspiegel, endorsed by King Alexander I Jagiellon), ${ }^{25}$ one to Bishop Bodzanta's Statute of Tithes of $1369,{ }^{26}$ one to the Royal Privilege of Jedlnia and Cracow of $1433,{ }^{27}$ and one to the collection of judicial oath formulas authorized by King Alexander I. ${ }^{28}$ The imbalance is hard to overlook. While the number of references to the Sachsenspiegel is kept at an absolute minimum, the reverse references are not that infrequent. ${ }^{29}$ It seems the authors of the Statutes worked with the intention to connect the Weichbild with the key texts of Polish law; cross-referencing it with the Sachsenspiegel was of lesser importance to them. The relatively higher number of reverse links from the Sachsenspiegel to the Weichbild may suggest that the latter was regarded as the base text.

Prior to the publication of Łaski's Statutes, there were several attempts to normalize the Latin Weichbild within the framework of the Silesian-Małopolska compilation. They resulted in the creation of the Sandomierz version and the Cracow version, with its Wawel variant. All of them, despite some flaws and lexical errors, are products of highly competent authors. Łaski's team surely shared this assessment of the high standard of these translations, or if they had been of a different opinion, they would have started work on a new version of the Weichbild, let alone a new translation of that key source. Collated from the versio Sandomiriensis and the Cracow version, supplied with a refurbished gloss, and cleaned up linguistically, the text of Łaski's Statutes marked the ultimate high point of the evolution of the medieval Weichbild in the Kingdom of Poland. The impact of that process on contemporary legal practice will be discussed below. My analysis is divided into four parts, which correspond roughly with four main rubrics in collections of Magdeburg Law: 1) the urban community and its citizens; 2) crime and criminal procedure; 3) family and rules of inheritance; and 4) debtor and creditor. These are the topics of provisions that were continually emended and modified. A comprehensive review of the themes of the Weichbild can be found in the Introduction.

Grodziski and Irena Dwornicka, eds., Volumina Constitutionum, Vol. 1: 1493-1549, vol. 1. 1493-1526 (Warszawa, 1996), No. 13, p. 63.

25 Reference from Article 56 , transposed into the Weichbild from the Sachsenspiegel.

26 Reference from Article 75 concerning the procedure to establish whether a man was free to provisions on tithes collected from knights and villeins.

27 Reference from the provision concerning a proxy in Article 93 to the royal Privilege of Jedlnia and Cracow (1433) is not clear.

28 Reference from the provision with the text of the Jewish oath (Article 108) to the formula of the Jewish oath.

29 Rymaszewski, Łacińskie teksty Landrechtu Zwierciadta Saskiego w Polsce. Versio, p. 169. 
The differences with regard to the urban community and its citizens are, for the most part, almost imperceptible. Occasionally, however, the traditional formulas do give way to completely new arrangements, especially in what can be described as constitutional matters, namely, the administrative and judicial competences of the city authorities and the status of guests (aliens).

\subsection{The Town Council}

The first provision of the Weichbild deals with the city council and the jurors. The city council are to be elected every year, while the jurors are to serve for the remainder of their lives. The latter, however, was not an absolute rule. ${ }^{30}$ The aldermen have the right to summon a meeting of the council whenever they wish, but they need to have the approval of the elders. The Żagań Ms, Łaski's Statutes, and the Leipzig ms gloss emphasize the role of the elders as a guarantee of proper management of urban affairs. The gloss in the Żegota Pauli's MS mentions 'senior aldermen' in this context. We may therefore assume that in Poland, the term 'elders' meant retired senior aldermen, although other interpretations are also possible. This passage was amended in St Petersburg MS (F 143, dated 1368), in which the word 'elders' is replaced by 'wise men.' ${ }^{31} \mathrm{In}$ that manuscript, Article 1 is thoroughly revised, probably with an eye to Polish realities. A reflection of those realities is most likely the addition stipulating that the aldermen elect the mayor (proconsul) from among themselves. ${ }^{32}$ This amendation must be seen in connection with another one in the St Petersburg MS and also in the Marcin Zabowski's Ms (dated 1513), namely, the skipping of the clause about Emperor Otto I granting the city of Magdeburg a charter on the advice of the council of elders. ${ }^{33}$

Article 1 acknowledges the validity of the town council's legislation unless it contravenes God's law. This clause was introduced by Konrad of Sandomierz and provides additional proof of Zygfryd Rymaszewski's claim that Konrad

$30 \quad$ See Maciej Mikuła, Prawodawstwo króla i sejmu dla matopolskich miast królewskich (13861572). Studium z dziejów rządów prawa w Polsce [Royal and Parliamentary Legislation for the Royal Towns of Małopolska (1386-1572): A Study in the History of the Rule of Law in Poland] (Kraków, 2014), pp. 195-202, 205-208.

31 No. 7. See: Maria Bogucka, Henryk Samsonowicz, Dzieje miast i mieszczaństwa w Polsce przedrozbiorowej (Wrocław, 1986), pp. 478-484.

$32 \quad$ No. 8.

33 No. 4 . 
believed in the primacy of canon law and God's law over secular laws. ${ }^{34}$ Normally, the latter must be obeyed, and the municipal authorities have the right to impose penal sanctions for their infringement. ${ }^{35}$ Article 1 describes the competences of the town council to hear complaints concerning weights and measures, food, and, more broadly, trade, where the offence was punishable in skin and hair or merited a fine of three Slavic marks or 36 shillings. Identical penalties are stipulated in Article 3, which is concerned with the use of false measures and weights. In the manuscripts of the Sandomierz version, the worth of the fine is set at 3 shillings, an obvious scribal error which goes back to Konrad's omission of ' 6 ' in the figure $36 .{ }^{36}$ The author of the Statues decided to follow the Cracow version with the correct figure and added an explanation that the penalty was intended to protect the interests of the poor. ${ }^{37}$

Both the Cracow version and Łaski's Statutes stress the role of the town council in defending the town's honour ${ }^{38}$ and in the fair and unbiased administration of justice. ${ }^{39}$ The high standards set for the aldermen were all too often belied by their conduct - hence the penalty of six denarii for those members of the council who failed to turn up at a session announced by bell ringing and five shilling if the summons was passed round by different means. ${ }^{40}$ This differentiation of the penalty may reflect the distinction between routine and extraordinary sessions, with the latter announced by the ringing of bells. This issue was additionally regulated in the municipal by-laws (wilkierze).$^{41}$ All in all, it seems that ill-disciplined aldermen were not hard to come by.

\subsection{Judicial Competences of Other Municipal Bodies}

The Weichbild was a basic law code of various types of courts. They included the grand Burggrafs court (iudicium provincialium), the grand sottys'/wójt's court, ordinary courts (iudicium bannitum), temporary emergency courts, summary

34 No. 1. Cf. Rymaszewski, Łacińskie teksty Landrechtu Zwierciadta Saskiego w Polsce. Versio, p. 213 .

35 No. 5 .

$36 \quad$ No. 10.

37 No. 12, and similarly in MS BN 3068. MS BN 3068 mentions loss of honour as an additional penalty for the use of false measures and weights (No. 11).

38 No. 3 .

39 No. 2.

40 Only in MS BN 12607 and MS BN 3068 is the fine for a sluggishness set at six solidi (shillings) (No. 6).

41 Maciej Mikuła, "O reformie prawa miejskiego w XVI wieku. Ciężkowicka uchwała o prawie prywatnym i administracji” [Reforms of Municipal Law in the 16th Century: A Statute concerning Private Law and Administration Adopted by the Municipality of Ciężkowice], Krakowskie Studia z Historii Państwa i Prawa 6/3 (2013), p. 229. 
courts, and guest courts (Gastgerichte). What I am interested in is the terminology and certain differences between the versio Sandomiriensis and the Cracow version of the Weichbild. ${ }^{42}$

The competences of the wójt (advocatus), the sottys (scultetus), and the Burggraf (castellanus) have been the subject of numerous in-depth studies which show that the meaning of these terms evolved when they came to be used in the medieval and 16th-century Kingdom of Poland. In the early 16th century, Johannes Cervus of Tuchola tried to reconnect the names of institutions and offices in the basic texts of the Saxon-Magdeburg Law with their counterparts in Polish towns. So, while the Grand Court of the Burggraf of Magdeburg was presided over by the Burggraf and the Schultheiß (sottys), ${ }^{43}$ similar courts in Cracow and Lviv' were headed by the major (burmistrz, Burgermeister), or an alderman officiating as his deputy, and the wójt (Vogt, advocatus).${ }^{44}$ 'Burggraf' is translated into Latin alternately as 'burgravius' and 'castellanus.' ${ }^{45}$ The use of latter term in the 16th century could be an indication that the kasztelan (castellanus) exercised real influence in municipal courts of royal towns and cities. ${ }^{46}$ Otherwise, the Burggraf or the kasztelan makes an

42 The section on the functioning of urban courts is one where we find a great deal of modifications introduced by the writers of individual manuscripts. Even if not all of them can be accounted for by the need to adjust the regulations of the Magdeburg Law, the general impression is inescapable. The accumulation of changes in that portion of text reflects the process of adaptation of the text of the law to local conditions, e.g. revised dates of court sessions. Cf. No. 14 (MS F 143, MS AJG and Ms Kiel.), No. 15 (MS BN 12607 and MS II Q 4) and No. 21 (MS F 143).

43 So in MS Q II 157 (1) in Środa Śląska [Neumarkt in Silesia], No. 201. See also: Wieland Carls, "Zur Verbreitung des Halle-Neumarkter Rechts in Schlesien", in: Halle im Licht und Schatten Magdeburgs. Eine Rechtsmetropole im Mittelalter, eds. Heiner Lück, (Forschungen zur hallischen Stadtgeschichte) 19 (Halle/Saale, 2012), pp. 191-201; Zbigniew Zdrójkowski, "Stan badań nad problematyką prawa średzkiego. Studium na 75o-lecie pouczenia miasta Halle dla Środy Śląskiej (1235-1985)" [Stan badań nad problematyką prawa średzkiego. Studium na 75o-lecie pouczenia miasta Halle dla Środy Śląskiej (1235-1985)] Czasopismo Prawno-Historyczne 37/2 (1985), 75-86; Zbigniew Zdrójkowski, “Geneza prawa średzkiego i jego rola dziejowa (1223-1511)”, Acta Universitatis Wratislaviensis. Historia 70 (1990), 53-67; Krystyna Kamińska, "Prawo średzkie jako instrument polityki osadniczej i gospodarczej w Polsce od XIII do początku XVI wieku”, in: Historia integra. Księga pamiatkowa ofiarowana prof. Stanisławowi Salmonowiczowi w siedemdziesięciolecie urodzin [Historia integra: A Festschrift in Honour of Professor Stanisław Salmonowicz on His 7oth Birthday], eds. Danuta Janicka, Ryszard Łaszewski (Toruń, 20o1), pp. 146-16o.

44 Władysław Bojarski and Zbigniew Naworski, Jan Jelonek Cereus z Tucholi i jego twórczość prawnicza. Ustrój sądów i prawo procesowe, [Johannes Cervus of Tuchola and His Legal Works: The Constitution of Courts and Procedural Law] (Toruń, 1993), p. 14.

$45 \quad$ No. 13 and 202.

46 Cf. another irregular situations: Witold Maisel, "Sąd miejski prawa polskiego w Kaliszu w XVI wieku" [Sąd miejski prawa polskiego w Kaliszu w XVI wieku], Czasopismo Prawno-Historyczne 23/2 (1971), 129-39. 
appearance in provisions concerning public order crimes like rape, assault, and house-breaking ${ }^{47}$ and in regulations concerning summary courts hearing cases of causae maiores crimes originally assigned (i.e. in the town charter) to the jurisdiction of the town founder. ${ }^{48}$

In one further case, the terms used about the administration of justice are highly significant. The Weichbild contains two articles taken over from the Constitution of Courts that deal with the trial of a sottys (der shultheize) and the wójt (der vogite), accused of abuse in the administration of justice. ${ }^{49}$ For some reason, the author of the Żagań ms replaced the word 'wójt' with 'Burggraf'; the Statutes uses both words at this point, which looks like a compromise solution. ${ }^{50}$ The legal glossary in Tomasz of Bydgoszcz's ms translates the term Burgrabius supremus as 'nawyssý sandzÿa grodszkÿ wýssego prawa' [supreme municipal justice of higher law].

One of the provisions enumerates the requirements that are to be met by the sottys (scultetus). Konrad of Sandomierz and Jan Laski, who follows the versio Sandomiriensis, adopt the regulation from the Magdeburg Bench Law (Das Magdeburg Schöffenrecht), adding to it the characteristic 'free' ('liber esse debet ${ }^{\prime}{ }^{51}$ It is worth noting that throughout that period, there was a keen interest in cataloguing personal qualities that a person holding public office should possess. We find such lists in both municipal wilkierze and royal legislation. ${ }^{2}$

The principles of the functioning of the sottys' and the Burggrafs court, as well as the composition of the jury (11 aldermen and the sottys), are laid down in the Constitution of Courts, appended to the Weichbild after the Jewish oath (Article 120 in the Statutes). Whereas not all of the Latin texts include the provisions of that supplement, the Statutes follows the Cracow version and adopts all of them.

47 No. 16. Crimes listed in Article 5 belong to the so-called four articles that are the prerogative of the captain, as defined by the 1423 Statute of Warta. That explains the appearance at Article 5 in the Statutes of a reference to f. XIV which features the relevant provision from the Statute of Warta. See Karol Koranyi, "W sprawie genezy czterech artykułów starościńskich" [The Origin of the Four Articles That Are the Prerogative of the Captain], Sprawozdania Towarzystwa Naukowego we Lwowie 11/1 (1931), 19-22.

48 No. 27 and 28. For exemplification, see No. 28.

49 In the Gniezno Ms, these provisions can be found in Articles 100 and 101.

50 No. 213. The use of the word 'sołtys' instead of 'wójt' in Article 100 (No. 206) is a scribal error committed by Konrad of Sandomierz.

51 No. 22. To establish his freeman's status, the burgher needed the oaths of six compurgators. In Marcin Zabowski's ms (No. 167), Article 75, which contains this provision, is for some reason corrupt. Cf. also individual emendations in Article 100 of the passage on sanctions faced by a sottys found guilty of a breach of duty (No. 207, 208, 209, and 210).

Mikuła, Prawodawstwo króla i sejmu, pp. 220-226. 


\subsection{Burghers and Guests}

The Weichbild is rather sparing in its treatment of burghers' duties and rights. More information on this subject can be found in Magdeburg judgments (ortyle) excerpted and incorporated into the Cracow version and the Statutes. Although the relevant passage is mainly concerned with heritable property (which is discussed below, in Section 5.2), it also mentions an oath taken in connection with the payment of municipal (property) tax. ${ }^{53}$ The Weichbild treats the subject of guests/aliens (hospes) from the point of view of their obligations. This problem will be discussed at length in Section 5.3. In the Żagań MS and the Statutes, the definition of a guest is expanded with a formula borrowed from an ortyl. To qualify as guest, a person must be at least 11 miles away from home or, according to the Statutes, at least 12 miles away from home. ${ }^{54}$ The amended figure in the Statutes corresponds exactly with the distance included in a similar definition in the Magdeburg's Instructions to Chetmno (Kulm).

\subsection{Summary: Modifications for Practical Use}

The modifications of the Weichbild text discussed here can be divided into four groups: 1) changes of terminology; 2) amendations and amplifications that took into account local legal practice; 3) legal definitions; and 4) supplementary doctrinal clarifications. The first of these categories is exemplified by the appearance of the words wójt (advocatus) and burgrabia (burgrabius) in the provision concerning judicial magistrates, which reflected the customary names of offices in the justice system of Polish towns. The amendations and amplifications in the provisions concerning jurors (as in the St Petersburg MS F 143) introduced, inter alia, the rule, common in Polish towns, that the mayor (proconsul) was elected by the acting aldermen. Legal definitions like that of a guest (hospis) in the Cracow version and in the Statutes were intended to eliminate and simplify possible controversies. Finally, the introduction in the Sandomierz version of the stipulation that municipal statutes must conform to God's law should come as no surprise; arguably, it enhanced the authority of the council as legislators. In short, the modifications of the Weichbild were clearly aimed at enhancing its use value and attractiveness (which implies that it was perceived primarily as a legal text for practical use).

$53 \quad$ No. 142 and 198.

54 No. 29. 
The catalogue of criminal acts in the Weichbild is not very long. It includes murder (with poisoning), wounding, rape, overt assault in the street, housebreaking, theft, and insult. The comparative analyses undertaken in the course of this study indicate that the model descriptions of criminal acts remain relatively intact along the lines of manuscript transmission. ${ }^{55}$ Generally, in the Weichbild, problems of crime and punishment are never treated separately from questions of criminal procedure. ${ }^{56}$ The code is made up of provisions whose large number makes the emergence of textual variants during the copy process practically inevitable. The majority of the alterations pertain to particular places in the text and are open to correction or a thorough revision - as happened to the Weichbild in taski's Statutes. However, in the history of the Weichbild, there are also two more complex and more tenacious sets of alterations which have given rise to two distinct versions of the original text: versio Sandomiriensis and versio Cracoviensis. They are different by virtue of the alterations which affect key problem areas featured in a code of criminal law. What follows is a comparative survey of their impact and evolutionary momentum, culminating in the text of Jan Łaski's Statutes rather than a systematic presentation of the Weichbild model of criminal law.

\section{1 'Who Started It?'}

According to the Weichbild, criminal liability and the severity of punishment depend on the circumstances of each act. Moreover, the regulations themselves allow room for the choice of trial depending on the conduct of the parties. The admission of the 'who started it?' question is just one example of how a plaintiff with a strong case could be thwarted. The Sandomierz and the Cracow versions (followed by text of the Statutes) of Article 37 differ in the delineation of the procedure when a suit is brought by both parties who participated in an affray. According to the versio Sandomiriensis, if one of the

55 For exceptions, see No. 119 - in the Działyńscy Codex IV, where 'poisoning' is replaced by 'killing'; No. 125 - in the Petersburg MS, the omission of a phrase naming the places where the breach of the peace took place; No. 161 - in MS Q II 157 (2) and in MS BN 12600 'poisoning' transferred from the main text to the rubric (2); No. 214 - only in the Żagań MS was the clause 'whoever commits house-breaking' broadened into 'whoever commits violence'.

56 Cf. Maciej Mikuła, "Czynniki ograniczające prawo retraktu w średniowiecznej Polsce" [Factors Limiting ius retractus in Medieval Poland], in: Studia z dziejów państwa i prawa [Studies in the History of the State and the Law], 9/1, ed. Jacek S. Matuszewski (Lublin Łódź, 2006), p. 1o9; and Jana Pacyna, Mittelalterliche Judenrechte. Norm und Anwendung im Magdeburger Rechtskreis (1250-1400) (Halle/Saale, 2015), p. 18. 
participants died of wounds, his agnate may sue the other party for murder. The defendant can then rebut the charge by claiming that he did not start the fight and clear himself by the oaths of six compurgators (metseptimus). Alternately, if the agnate of the deceased were to demand an ordeal, the defendant would have no choice but to take up the challenge. Were he to lose the duel, he would also lose his life. While the general rules are common to all versions, the Cracow version and the Statutes supplement them with some specific regulations. Only the Statutes upgrades the ordeal by combat as a decisive means of proof by allowing the agnate of the deceased to resort to it in addition to the summoning of the oath-helpers. ${ }^{57}$ The Statutes also follows the Cracow version in insisting that for the defendant, the lost duel is tantamount to a death sentence. ${ }^{58}$ The provision concerning the time allowed to the defendant for mustering his oath-helpers is modified, too. Out of three fortnightly sessions, he has to choose one. The Sandomierz version merely stipulates that the compurgation should take place in the course of six weeks. ${ }^{59}$ Only the Statutes reinstates the provision that the defendant needs the oaths of six men to acquit himself of the charge of having begun the fray. In the Sandomierz and the Cracow versions, this mode of trial is mentioned several times, and the Statutes reproduces all such mentions from both versions. ${ }^{60}$ Thanks to its numerous explanations and supplements, the provisions of the Statutes seem to be clearer and more precise.

\subsection{Aiding and Abetting}

Article 12 of the versio Sandomiriensis stipulates that the number of the individuals accused in a case of wounding must not exceed the number of wounds. ${ }^{61}$ If the plaintiff lays charges against a larger number of people, those who are above that limit can clear themselves by the oaths of six compurgators. In the Cracow version and the Statues, this provision is given a different interpretation. The eventuality that a larger number of persons than the number of inflicted wounds may be liable is not ruled out. The supernumerary defendants that are charged with aiding and abetting the crime of murder or of injury meriting a duel (vulnus duellaris), with the latter called 'fatal wounds' in the glossary of the Magdeburg Law terms in the Tomasz of Bydgoszcz's ms. Those defendants could acquit himself of the charge by their own oaths. But if the charge was backed by testimonial evidence, two compurgators were still

$57 \quad$ No. 8 o.

$58 \quad$ No. 82.

$59 \quad$ No 83 .

6o No. 81 and 83 . Only in the Działyńscy Codex IV was this time limitation reduced to two oath-helpers (mettertius).

$61 \quad$ No. 35 . 
needed. These additional clauses can only be found in the Baworowscy Ms and the Żagań ms (i.e. the bilingual manuscripts of the Cracow version).

\subsection{Court Procedure}

Magdeburg Law envisages not only the institution of the attorney, ${ }^{62}$ but also allows in certain circumstances the father to act on behalf of his son. The regulations concerning the latter eventuality are copied verbatim and even duplicated in the manuscripts. One such duplication occurs in the Statutes. The clause which requires the father who wants to represent his son to clear himself first from the charge brought against him and his son is included, following the Sandomierz version, in Article 24 and also, following the Cracow version, in Article 86 (in the numbering scheme of the Statutes). ${ }^{63}$

The amount of time that passed between the commission of a crime and the formal accusation was of considerable importance (i.e. the right to precedence in presenting evidence) ${ }^{64}$ In particular, according to Article 10, the plaintiff's putting off of court action to the following day gave the accused the right to produce six oath-helpers to clear himself of the charge. The text of that provision in the Statutes, following the Żagań Ms, omits the justification of this rule. ${ }^{65}$ Likewise, the Statutes follows the Żagan ms in expanding Article 33 concerning counter-charges. In the latter case, the Statutes mirrors the matching German text of the Żagań Ms dealing with case of combatants brought before the court after being caught in the act (in facto manifesto) of duelling.66

Both the Cracow version and the Statutes insist that neither the plaintiff nor the defendant is in charge of the legal proceedings, asserting that it is the judge who plays that role. It is worth noting that this supplementary clause is included in the provision allowing the latter to deal summarily (outside the court calendar and the officially designated places) with a case of recovery of debt where no oath-taking was required. ${ }^{67}$ The Statutes, following the addition in the German and Latin text of the Żagań Ms, also reaffirms the obvious rule that both the judge (i.e. Burgraf/kasztelan/wójt/sottys) and the jurors are involved in the decision-making. ${ }^{68}$ If the jurors could not make up their

62 Cf. amendations in MS Q II 157 (1), MS Q II 157 (2), MS BN 126oo, MS Dział. IV, and MS II Q 4 concerning the criteria that have to be met by an attorney representing a party in the trial (No. 120).

$63 \quad$ No. 58 and 188. Cf. also No. 59 and 187.

64 For various individual variants see No. $31,32,34,67,68,70,127$, and 189 .

65 No. 33.

66 No. 75.

67 No. 18o. Cf. MS BN 3068 where the instrument of summary procedure without witnesses can be applied in actions other than recovery of debt (No. 179).

68 No. $150(430)$. 
mind, they had the right to postpone the decision until - at the latest - the second session in a row. This supplementary clarification was borrowed from an ortyl. $^{69}$

\subsection{Proof}

The Weichbild admits the following types of proof: oath, collective oath compurgation, the ordeal (duellum), and inquest (inspection). ${ }^{70}$ That list may be extended to include hearings, since the code allowed a challenge of witness testimony (pro falso). ${ }^{71}$ Moreover, Article 53 provides for the dispatching of three persons to the injured person to find out about his condition and report back to the court. ${ }^{72}$ The outcome, not only in a criminal court, depended on the right to precedence in presenting evidence to the attention of the court. That condition needed no further deliberation when the perpetrator was caught in the act and the evidence was at hand. ${ }^{73}$ In other circumstances, the right to precedence in presenting evidence was established according to precise rules, which are discussed in the Introduction (cf. a synopsis of the contents of Ius municipale Magdeburgense) and in Section 3.1.

While the largest number of amendments deals with the administration of the oath and the compurgators, most of the modifications are peculiar to individual manuscripts. In the Statutes, the modifications concern Article 37 (as indicated earlier in Section 3.1), that is, the time limit of the compurgation in cases of fatal wounding in an affray. Moreover, the Statutes follows the Cracow version in replacing the six-week time limit with a clause allowing the defendant to choose one of successive two-week periods in which the oath is to take place. ${ }^{74}$ This is further modified by a rule granting the judge the right to adjourn the proceedings if the time limit expired on a public holiday (one of

\section{$69 \quad$ No. 193.}

70 Article 65. Cf. No. 154 with variants in the Częstochowa MS and the Kielce Ms.

$71 \quad$ No. 108.

72 A minor modification of that rule appears in the Działyńscy Codex I and MS BN 3068, where a clause that the statement before the court is to be made by one of the 'inspectors' is omitted (No. 121).

73 Minor modifications occur in No. $74,114,115,116,117,118,120$, and 176. Cf. the discussion in Section 5.1.

74 No. 83. In the early modern period in the towns of Royal Prussia, the time limit for the administration of the oath (iuramentum) was usually one week. See Piotr Kitowski, "Przysięga dowodowa w polskim prawie miejskim i ziemskim w XVII-XVIII wieku" [The Evidentiary Oath in Polish Municipal Law and Polish Land Law in the 17th-18th Century], in: Nil nisi veritas. Księga dedykowana Profesorowi Jackowi Matuszewskiemu [Nil nisi veritas: A Festschrift in Honour of Professor Jacek Matuszewski], eds. Marcin Głuszak and Dorota Wiśniewska-Jóźwiak (Łódź, 2016), p. 326. 
the dies feriatos). ${ }^{75}$ Additionally, the rigidity of the formal procedure was softened by an amendment allowing a stutterer to go through the formulae of the oath for a second time. An important amendment of the Weichbild text in the Statutes, inspired by the example of the Cracow version, concerns the possibility of retracting the promise of swearing an oath. ${ }^{76}$ However, this clause must be read in the context of the original provision of Article 97, that is, if anybody binds himself by promise to swear an oath before the court in an action for insult, robbery, assault, or bloodshed, he cannot absolve himself from that obligation unless he has the permission of the court. This amendment treats in a similar manner the situation when it is the plaintiff's intention to absolve the defendant from his promise. The failure to obtain the judge's permission and to swear the oath as promised is punished by a mulct (a fine for a judge) of no more than eight shillings, which is be imposed for each instance of noncompliance separately. The Jewish oath, too, is subject to various amendments in the individual manuscripts. The changes concern the details of the ceremony, the oath-swearer's dress and gestures, ${ }^{77}$ and the wording of the oath itself. ${ }^{78}$ In fixing its own formula of the iuramentum Judaeorum, the authors of the Statutes drew on the texts of the Cracow and the Sandomierz versions.

In the manuscripts, numerous amendments were introduced regarding the number of compurgators, which varies from two to six. Many of the changes appear to be dictated by common sense, as in the case of the Działyńscy Codex IV, reducing their number from six to two in bringing in the charges of rape, assault, house-breaking, murder, theft, or robbery when the perpetrator was caught in the act. ${ }^{79} \mathrm{~A}$ clear delimitation of the number of persons required to participate in a given procedure is a characteristic feature of the Statutes, which, in this respect, follows the text of the Żagan ms and the German base. Therefore, for example, the charge of insult of a court official could not be

$75 \quad$ No. 158.

76 No. 200.

77 No. 219, amended in MS Q II 157 (2) and MS BN 126oo.

78 No. 220.

79 No. 113. Additions that are fully appropriate include the requirement that the owner of stolen goods is to prove ownership by swearing an oath in MS BN 3068 (No. 87), or that the seven compurgators are to deliver proof (swear an oath tacto sacramento) of no consanguinity (consanguinity was also a legal hindrance in judicial ordeals) in the Baworowscy Ms, the Opatów Ms, and the Żagań Ms (No. 130). Cf. also No. 92. On the other hand, there are amendments that cannot be called improvements, like the one in MS Q II 157 (1), No. 56 (an obvious scribal error) or the omission of the number of compurgators in MS Q II 157 (1), No. 19o. Sometimes, however, the missing number at one point in the text does not matter, for it is mentioned in other provisions that are appropriate, as in No. 215. 
admitted unless backed by the judge and 'two' jurymen. ${ }^{80}$ The details of the judicial combat carefully regulated in Article $5^{6}$ on the basis of the provisions of the Sachsenspiegel were also subject to modifications in individual manuscripts. Thus, according to the Żagań Ms and to the Statutes, not only the judge but also the court usher had the right to warn the members of the audience that interference in the ordeal was a capital offence. ${ }^{81}$

\subsection{Recompensa, Emenda, Pena}

In the Latin Weichbild, punishment is referred to by several different words. The term pena seems to refer consistently to a mulct. Recompensa is translated in the Latin-Polish glossary of the legal terms of Magdeburg Law in Tomasz of Bydgoszcz's MS as 'zapłata głowna' (lit. the price of a man's head; wergild). ${ }^{82}$ 'Emenda' (amends) is translated in this manuscript as 'pokup', or damages. In accordance with the German text, manum means '[the cutting off of] the hand', and collum (neck) means decapitation. In the latter case, checking the German text dispels any doubts that the word may refer to poll tax. The penalties in all their aspects are subject to considerable modifications in the manuscripts. Most of those amendments were ultimately passed over by the authors of the Statutes. ${ }^{83}$ The clauses that echo the provisions of the Chełmno Law concerning the payment of wergild (up to twelve weeks), mulct (up to six weeks), and compensation (up to 14 days after mulct) are an exception. ${ }^{84}$ The same is true for the clause, taken over from an ortyl in the Cracow version, setting down

$80 \quad$ No. 205. In the Częstochowa Ms and the Kielce Ms, the requirement of proof delivered by oath-helpers is omitted in the action concerning insult of a member of the jury (No. 192).

81 No. 134. A number of amendments are peculiar to the Żagań ms, e.g. the omission of the requirement to swear an oath before the judicial combat by both parties (No. 137). For other changes concerning the duel, see No. 78, 128, 129, 131, 132, 133, 135, 136, 138, 139, 140, and 153 .

82 In the modern Polish translation of the Old Chełmno Law (Der alte Kulm) both weregelt and recompensa are rendered as 'główszczyzna' or 'zapłata głowna' (lit. the price of a man's head), PS II.31/37. Cf. Aleksander Zajda, Staropolska terminologia prawnicza (do 1500 r.) [Polish Legal Terminology (until 1500)] (Kraków, 1990), p. 193.

83 E.g. reduction of the mulct for the kasztelan by half (No. 20, in connection with No. 19, and also No. 25); fixing the amount of compensation to a man beaten with sticks over the head and the back at 30 shillings and a mulct of eight shillings (No. 155); damages of 30 shillings for jurors insulted in court (No. 191). Clauses omitted in various manuscripts and nonetheless do appear in the Gniezno MS and the Statutes; see No. 55, 138, 194, 203, 204, and 209. Conversely, for variants concerning extrajudicial agreement peculiar to individual manuscripts that are not taken over by the Statutes, see No. 55, 56, 57, and 69. Cf. also a variant that occurs only in MS Q II 157 (1) concerning res iudicata that is not included in the Statutes (No. 157).

84 No. 17 , and in MS BN 3068 additionally No. 18. 
the pledge guaranteeing the appearance in court of a defendant accused of murder. If the accused were to flee, his responsible surety would have to pay the judge the 14 pounds wergild and a mulct of eight shillings. ${ }^{85}$ The Statutes does not include, however, a clause added in the Żagań Ms which stipulates a mulct of 9 shillings for wounding. It is equally unclear why the Statutes leaves out a clause which states that a recompense amounting to half of the wergild is be paid to the plaintiff by a sottys who failed to issue a judgement in a case of wounding, even though the perpetrator had been brought before the court. ${ }^{86}$ The Statutes follows the Cracow version in confirming that theft during daytime is to be punished in skin and hair if the perpetrator has a good reputation and the value of the stolen goods does not exceed three shillings. The manuscripts of the versio Sandomiriensis use at this point the phrase 'less than three shillings'. The difference could not have been more trifling, yet it illustrates the subtlety of the changes introduced by individual copyists. ${ }^{87}$

\subsection{Summary: Concern for Clarity}

The modifications in the area of criminal law seemed to have had three main purposes. The first of such purpose was to eliminate ambiguity and uncertainty. Thus, for example, the Weichbild is not clear about whether in a case of serious crime the party that was given precedence in the order of the trial had the right to choose a judicial duel (wager by battle) or the accusatory oath. The Statutes cleared up this difficulty. Clarification often went hand-in-hand with ensuring the inner coherence of the Weichbild regulations. For example, the wójt (Vogt) or sottys (Schultheiss) had the right to adjourn a court session until the following day after a holiday, but apparently had no right to do likewise in the case of oath-taking trials. The Statutes did away with this ambiguity, too, by introducing a uniform rule. Whereas some modifications were simply regulatory (e.g. the introduction of precise time limits for the payment of court fines), the third purpose, or perhaps tendency, is to soften the edges of some rules, such as lowering the maximum number of oath-swearers or making adjustments for people who stammer.

85 No. 24. Cf. also the regulation - found only in MS BN 3068 - concerning the retraction of a promise to swear an evidential oath (No. 212).

86 No. 211.

87 No. 84. Cf. also No. 86, where a substantial passage concerns the seizure of the property of a man accused of wounding and killing towards the payment of compensation (wergild) and mulct in MS Q II 157 (2) and MS BN 126oo. Cf. also No. 194. 


\subsection{Agnatus and Cognatus}

Amendments concerning marriage, inheritance, and guardianship law can be found in several Weichbild texts. A modification of considerable significance concerns the terms agnatus and cognatus. The Statutes took over the definition of this pair of words from the versio Sandomiriensis and applied it with great consistency. ${ }^{88}$ The Cracow version does not appear to be aware of this supplementary clarification and makes no distinction between a cognate and a relative. That could lead to some confusion. Thus, Article 50 in the Gniezno Ms states that guardianship falls to the nearest agnate of the children. However, in a number of manuscripts, we can find at this point the term cognatus, and the Opatów Ms. features both terms. In the Działyńscy Codex I, the text uses the term cognatus, but the copyist inserted a superscript $a$ over the co. The latter two examples indicate that at least some copyists were not sure of which term to use. In this context, it is worth noting that the legal glossary attached to Tomasz of Bydgoszcz's Ms provides not only Polish equivalents of Latin terms, but also brief definitions - in this case, Agnati dicuntur successores post patrem and Cognatus successor post matrem. ${ }^{89}$

\subsection{Guardianship}

According to Article 5o, guardianship is a legal obligation that falls to the nearest male relative of a fatherless child, and if that agnate were to be underage, it would fall to his nearest male relative. The Statutes employs the term agnatus, citing the first part of this provision, but omits the second part which refers to the situation when the primary guardian (adiutor, tutor) is a minor and thus incapable of exercising the custody. ${ }^{90}$ The guardian's duties included the accounting of his administration of the ward's property in annual reports. If a deputy guardian was appointed, for example, when the primary guardian was still a minor, he was obliged to present his account accompanied by the latter (coram vero tutor), and according to the Baworowscy Ms and the Opatów Ms, also in the presence of aldermen or jurymen. This provision is missing from the Statutes, which, as we have noted, passes over the problem of deputy guardianship. ${ }^{91}$ The question of accounting is raised again in Article 74, where a distinction is made between children up to the age of 12 (in pupillari aetate) and adolescents. The latter had the right to choose his guardian (curator), who,

\begin{tabular}{ll}
\hline 88 & No. 166. \\
89 & MS BN 3068, f. 224r and 224V. \\
90 & No. 111. \\
91 & No. 112.
\end{tabular}


when appointed, was obliged to render account of his administration of his ward's property to the minor and the child's mother. ${ }^{92}$ In this description of the rights of the adolescent, the Statutes follows an ortyl incorporated into the Cracow version. Even when placed under the care of a guardian, the minor from the age of 12 had certain legal rights - for example, the right to dispose of property, although in the case of heritable property, he could not act without the heirs' consent. ${ }^{93}$ The mature minor is not exempt from adult systems of legal responsibility and prosecution. This regulation has to be read in conjunction with Article 96, which states that until the appointment of a guardian (verus tutor), the minor up to the statutory age of puberty was exempt from prosecution. Article 50 of the Statutes refers to a provision in the Statutes of Kazimierz the Great which forbids both the alienation of the ward's property and litigation against a minor in pupillari aetate. The prohibition of the sale of the ward's property (unless it is necessary to finance the minor's needs and the guardian has obtained the permission of the judge) also features in the additional Article 140 in Paweł Szczerbic's Ius Municipale (1581).

\subsection{The Dower}

The Magdeburg Law restricted the legal capacity of the widow or widower to inherit property from a deceased spouse. The only way the right of succession of the surviving spouse could be guaranteed was by a will inter vivos. These dispositions usually concerned the widow's jointure and the dower (wiano, dotalitium) ${ }^{94}$ This was the main change in comparison with in the Sachsenspiegel, in which the principal instrument was the 'morning gift' (Morgengabe). The modifications of the text in the Weichbild refer to the rights of the widow to administer the property that belonged to her deceased husband or a minor child. ${ }^{95}$ The modifications clarify the rules under which she was able to hold on to assets that were bestowed upon her during her husband's lifetime. Most important in this respect is Article 14, which lays down the general rule that a widow does not succeed to her husband's estate apart from the portion she was given as her dower (pro dotalitio aut vite provisione). ${ }^{96}$ That

92 No. 164.

93 No. 165.

94 In contrast to the Magdeburg Law, the Chełmno Law affirms the principle of joint ownership for married couples which entails considerable differences in their rights of survivorship. The problem is dealt with in Ms Dział. IV, which contains a supplement In Colmense appended to the articles of the Weichbild (cf. Chapter 4).

95 Cf. No. 162.

96 The translation of Morgengabe as dotalitium shows how the term was understood in medieval Poland. See Margret Obladen, Magdeburger Recht auf der Burg zu Krakau: Die güterrechtliche Absicherung der Ehefrau in der Spruchpraxis des Krakauer Oberhofs (Berlin, 2005), Chapter 3 on the dower, and especially the conclusions, p. 130; Nataliia 
estate, as per Article 14, is to revert to the heirs of her husband upon her death. If the husband did not assign a dower, the widow had the right to remain in the family home and claim support from their children. She forfeited those rights upon remarriage. If her dower were to be disputed, a widow could validate her claim by summoning seven oath-helpers. ${ }^{97}$ Both men and women were eligible for this wager of law. This provision was heavily criticized by Bartłomiej Groicki, who cited numerous examples of its abuse by widows. However, its efficacy was weakened by municipal legislation (wilkierze).${ }^{98}$ Further clarifications of the widow's interest were introduced by the ortyle; these amendations became part of the Cracow version and then incorporated into the Statutes. ${ }^{99}$ They regulated the issue of dower assets that were encumbered by debt. If the dower assignment was in the form of cash, the payment of the debts due from the deceased husbands came first; if, however, the dower was assigned in heritable property, the order was reversed. The assumption was that a husband was free to establish a dower in real estate which he could freely alienate (i.e. 'acquired property' as opposed to 'inherited property'), as well as in chattels.

\subsection{The Compulsory Portion (Mußteil), Gerada, and Hergewet}

The problem of the elements of a deceased person's estate is addressed in the Weichbild in four separate articles, which reflect the polyphonic structure of the compilation. Article 26 was originally part of the Magdeburg Bench Law (Magdeburger Schöffenrecht, Art. 46); Articles 6o and 61 came from Magdeburg's Legal Instructions for Wroctaw (Rechtsmitteilungen Magdeburgs

Ivanusa, Frauen im Sächsisch-Magdeburgischen Recht. Die Rechtspraxis in kleinpolnischen Städten im 16. Jahrhundert (Studien zur Ostmitteleuropaforschung) 38 (Marburg, 2017), pp. 137-138, and 143-149. The modern translation of the Old Chełmno Law (Der Alte Kulm) uses the word 'podarek poranny' (literally 'Morgengabe') (PS III.39-41, pp. 110111). Paweł Szczerbic in his translation of the Weichbild uses the word 'wiano' (dower) (SzIM, Article XxII, pp. 107-118). On the Polish equivalent of the term Morgengabe as wiano (dower) in the Polish translation of the Magdeburg ortyle, see Inge Bily, "Der Rechtsterminus Morgengabe im deutsch-polnischen Sprachvergleich (untersucht auf der Grundlage eines frühneuhochdeutschen und eines altpolnischen Textes der Magdeburger Urteile)", in: Deutsch-slawische Kontakte - Geschichte und Kultur. Festschrift für Mária Papsonová, eds. Michaela Kováčová, Jörg Meier, and Ingrid Puchalová, (Acta facultatis philosophicae Universitatis Šafarikinae) 12 (Kosice, 2011), pp. 115-125.

97 The number of compurgators is omitted in MS BN 3068 (No. 39).

98 Bartłomiej Groicki, Tytuty prawa majdeburskiego [Titles of the Magdeburg Law], ed. Karol Koranyi, Biblioteka Dawnych Polskich Pisarzy-Prawników [Library of Ancient Polish Jurists] 3 (Warszawa, 1954), pp. 48-49. See also Mikuła, "O reformie prawa miejskiego w XVI wieku", pp. 238-239.

No. 44 . 
für Breslau) of 1261 (Articles 62 and 63); and Article 94 came from Magdeburg's Legal Instructions for Wroctaw of 1295 (§ 18). .100

According to the Weichbild, the deceased's property was divided into the gerada (Ger. Gerade, Lat. suppellectilia), which fell to the closest female relative; the hergewet, inherited by the male successors; and the general inheritance (dziedzictwo). The gerada excluded a special category of food (pulmentaria), called rzeczy strawne in Szczerbic's translation (the latter mirrors the German term Mußteil). The manuscripts differ chiefly by the scope of the inventories of items of the gerada (usually clothes and kitchen utensils), but in no case is there any alteration of the inheritance rule itself. ${ }^{101}$ While some lists are more detailed, some do not include items that are mentioned elsewhere (presumably to avoid repetition). ${ }^{102}$ Amendments in the scope of the inherited property are introduced, following the example of the Cracow version (or the Żegota Pauli's MS), by way of a supplement which stipulates the division of the gerada into two equal shares between heirs if one of them was a clergyman. ${ }^{103}$ This rule remained intact until the introduction of a major reform which paved the way for it to be altered by wilkierze (municipal by-laws) approved by the king or the town's feudal landlord. ${ }^{104}$

100 A counterpart of Article 26 discussed here is not included in the vulgate, nor can it be found in Jaskier's or Szczerbic's editions of the Weichbild. This article contains a broad list of items that should be treated general inheritance (dziedzictwo).

101 Cf. Piotr Suski, "Spory wokół gerady i hergewetu w polskim miejskim prawie spadkowym w XVI w". [Debates about gerada and hergewet in Polish Urban Inheritance Law in the 16th Century], in: Prawo blisko cztowieka. $Z$ dziejów prawa rodzinnego i spadkowego [The Law and the Ordinary People: From the History of Family and Inheritance Law], ed. Maciej Mikuła (Kraków, 2008), pp. 168-169; Urszula Sowina, “Trousseau according to the Ius municipale Magdeburgense by Paweł Szczerbic and the position of a woman in the craftsman family at the beginning of the early modern time", Kwartalnik Historii Kultury Materialnej 68/4 (2020), pp. 494-506.

102 No. 42 and 195. It is not clear why the item 'objects permanently attached to the property' is excluded from the gerada list in the Petersburg Ms (No. 66).

103 No. 49. With regard to clergymen who opted out of the land law jurisdiction, the Statutes has taken over the supplementary regulation of the Sandomierz version (cf. No. 148). More precise definitions of the person eligible for the gerada can be found in the Przemyśl ms (the gerada falls to the agnate and cognate female relative) and in MS BN 3068 (sisterin-law), while other texts refer to a cognate female relative or simply a female relative (which, however, depends on the meaning of the term cognata (No. 143). See Maciej Mikuła, "Modyfikacje łacińskich tekstów Weichbildu magdeburskiego a ewolucja prawa w średniowiecznych miastach polskich. Uwagi wstępne" [Modifications of Latin Texts of the Magdeburg Weichbild and the Evolution of Law in Medieval Polish Towns: An Introduction], in: Acta Iuridico-Historica Pilsnensia, 2012-2013 (published 2014; ed. Vilém Knoll), p. 147 .

104 Maciej Mikuła, "Die Könige und das Reformationsverfahren des Rechts in den polnischen Städten vom 14. bis zum 16. Jahrhundert”, Beiträge zur Rechtsgeschichte Österreichs 2/2 
Amendments concerning the compulsory portion are on the whole left out of the Statutes; ${ }^{105}$ those that are included merely clarify a given provision. Therefore, for example, Article 6o, following the Żagan ms, expressly bars a female relative from that portion, although it should be clear from the context. ${ }^{106}$ Another point worth noting is that Article 26 refers to the compulsory portion of the widow (and not a female relative of the deceased), while Article 60 lists items that fall to the widower.

As the Saxon hergewet, with its focus on armour and war horses, was hardly relevant for the burghers, it became an obvious target of the urban law reform, which gave more scope for wilkierze approved by the king or the town's landlord. The supplementary amendation, taken over from the German base which stipulates that a grandson born to a female heir is not entitled to inherit his grandfather's armour (it is to be handed over to the judge) ${ }^{107}$ - is missing from just a few manuscripts. ${ }^{108}$ This regulation was introduced to deal with a case in which the line of succession to the herewet is first broken as the deceased person has no sons and then appears to be restored when his daughter gives birth to a male child. The law made to resolve this problem affirmed the validity of the general rule that the herewet cannot fall to and be transmitted by a female heir.

\subsection{Rules of Succession}

When it comes to the devolution of a deceased person's real property, the Weichbild distinguishes between heritable freehold, heritable leasehold, and property acquired during marriage. These categories are essential in determining the property's alienability. ${ }^{109}$ All transfers of property acquired during marriage (although some manuscripts of the versio Sandomiriensis do not contain that clause) ${ }^{110}$ are excluded from the claims of heirs. ${ }^{111}$ According to the Weichbild, property can be acquired through purchase, gift, or pledge. ${ }^{112}$ The law protects the owner of both acquired and inherited property; ${ }^{113}$ it also

(2013), p. 504; and Mikuła, Prawodawstwo króla i sejmu, pp. 280-286, which includes a bibliographical list of earlier studies.

105 No. 63 and 65.

106 No. 144.

107 No. 106.

108 The Gniezno ms, the Działyńscy Codex I, the Przemyśl ms, and Marcin Zabowski's Ms.

109 No. 62 and 103.

110 Especially in the Leipzig Ms and the Tomasz of Bydgoszcz's Ms, No. 104.

111 No. 102.

112 No. 89.

113 No. $5^{\circ}$ and 199. For an exception from the rule of quiet possession, see the St Florian Ms, No. 100. 
upholds the principle of acquired rights, namely, that a donor cannot give away the same item of property twice. ${ }^{114}$

The assets of inherited and acquired property which did not count as gerada, the compulsory portion, or hergewet constituted the general inheritance (dziedzictwo). Konrad of Sandomierz refers to the acquisition of their inheritance by the heirs at law as a natural right, as does the Statutes. ${ }^{115}$ To prove his title to succession in court, the heir has to present a number of landowning oath-helpers. In most manuscripts, their number is set at six, except for the Działyńscy Codex IV, where it is reduced to two. ${ }^{116}$ The right of succession is not affected by the decedent's misconduct or negligence. A supplementary amendment, taken over from an ortyl, reaffirms this principle with regard to assets whose true value was concealed by the decedent to evade taxation. The heir cannot be stripped of his estate unless he relinquishes his rights to it by an express waiver before the court or an assembly of aldermen (acting in their official capacity). In that case, the aldermen are responsible for managing or disposing of the released assets to benefit the urban community.117 This provision complements another one from an ortyl attached to Article 58 of the Statutes (following the Cracow version), which says that whoever conceals his assets to evade taxation and then admits that they belong to him is guilty of perjury and, in effect, loses his burgher's rights. ${ }^{118}$

As a rule, the general inheritance falls to the deceased's children. Article 25, however, stipulates that upon the wife's death, if the couple has no children, the surviving widower has a claim on the property acquired during marriage prior to her relatives, provided he was her equal in honourable status: ${ }^{119}$

Si moritur femina absque herede, ita quod nullum heredem a suo marito pepererit, ipsa heredat sua successoria, seu sua prospera fortuna acquisita super suum proximum naturalem successorem, sive sit masculus sive femina, qui sibi sit paris condicionis. Idem facit vir illi, qui sibi paris fuerit condicionis.

This passage reproduces the German text of Magdeburg's Instructions for Wroctaw of 1261, the Magdeburg Bench Law, the Wawel Ms, and BJ 170a; however, the latter sentence is missing from the Cracow Ms. ${ }^{120}$ The omission can

\footnotetext{
114 No. 100.

115 No 90 and 91.

116 No. 92, 93, and 94 (the divergence in the Opatów Ms is probably due to scribal error).

117 No. 198.

118 No. 142.

119 No. 62.

120 Appendix 3, No. 341.
} 
be interpreted as an additional condition: to acquire the estate, the widower has to have no lesser status than the other claimants (i.e. the relatives of his deceased wife). This condition does not appear in the Latin manuscripts of the Cracow version, but, following the versio Sandomiriensis, it resurfaces in the Statutes.

Another important modification is introduced by an ortyl attached to Article $73 .{ }^{121}$ According to the Statutes, if the children who had inherited the main estate (dziedzictwo) after their father's death died before their mother, it would fall to her. After her death, the estate would then fall to her closest relatives, regardless of whether they were agnates or cognates. The ortyl also states that the dziedzictwo (general inheritance) cannot be alienated without express approval of the heirs. This condition does not apply to moveables or to property acquired during marriage.

In accordance with the general rules of inheritance under the Magdeburg Law, the preferential order of succession and distribution includes descendants, ascendants (parents), brothers and sisters, and extended family. ${ }^{122}$ In the most distant class (the extended family), the Statutes, following the Żagań Ms, gives no preference to male or female heirs and treats the matrilineal and the patrilineal lines equally. ${ }^{123}$ The Statutes also addresses certain more complex or puzzling cases by drawing on the judicial wisdom of the ortyle. One such issue arises when the estate is distributed among (some of) the children before the death of their father. The general rule in Article 14 says that the children who have already received their share are excluded from the distribution of the property left at the time of their father's death. ${ }^{124}$ Only if one of the children (implicitly, without offspring) died after their father's death, would his estate be distributed among the rest regardless of whether they were excluded. ${ }^{125}$ The

\footnotetext{
121 No. 163.

122 Cf. Ludwig Meuten, Die Erbfolgeordnung des Sachsenspiegels und des Magdeburger Rechts. Ein Beitrag zur Geschichte des sächsich-magdeburgischen Rechts (Frankfurt am Main, 200o), pp. 150, 197, 208 and 225; and Piotr Kitowski, Sukcesja spadkowa w mniejszych miastach województwa pomorskiego w II potowie XVII i XVIII wieku. Studium prawnohistoryczne [Inheritance Succession in Small Towns of the Voivodship of Pomerania in the Late 17th-18th Century: A Study in Legal History] (Warszawa, 2015), pp. 50-51. For more individual variants in passages referring to inheritance law, see No. 98, 99 and 105.

123 No. 48.

124 A notable variant in No. 41: the appearance in the Latin text of the term exhereditatus. It can, of course, mean 'disinherited', but in the context of the whole passage, it almost certainly refers to heirs that have already received their portion of the patrimony. (Stownik taciny średniowiecznej [A Dictionary of Medieval Latin], 3, compiled by Marian Plezia and Julia Mruk (Wrocław - Warszawa - Kraków, 1969), col. 1396).

125 For variants, see No. 43.
} 
ortyl attached to Article 48 regulates the question of succession in the situation when a son dies before his father by making it dependent on whether he has already taken his share. However, the problem becomes more complicated if the prematurely deceased son has children. In that case, if he was not excluded, the estate was distributed equally between the grandchildren and their uncles. If, however, the deceased son was excluded, his children would get equal distributive shares in the portion that fell to their father, ${ }^{126}$ and, in all probability, be worse off for the exclusion. In either case, the children of a daughter do not inherit from their grandfather if there are other living heirs descended from his sons. The latter restriction does not apply when the devolved estate was owned by their grandmother.

The texts of the Cracow version, the Statutes, and the Przemyśl manuscript contain an aphoristic instruction on how to ensure the equal division of the inheritance: senior dividit et iunior eligit ('the elder brother carves up, the younger brother picks out'). ${ }^{127}$ Another addition relating to the division of the inheritance - namely, that each of the co-heirs has the right to demand and receive his separate share of the estate - can be found in the Statutes and in the Cracow version. ${ }^{128}$

\subsection{Deathbed Gifts}

A thread that runs through all of the texts of Weichild is the rule declaring all deathbed dispositions of property (donatio in lecto egritudinis) whose value exceeds three shillings invalid unless it is approved by the heirs. The Sandomierz version, however, omits a clause prohibiting wives to makes deathbed gifts without their husbands' permission. On this point, the Statutes follows the Cracow version, which sticks to the German base. ${ }^{129}$ In late editions of Weichbild - Mikołaj Jaskier's and Paweł Szczerbic's translations - the wording of this provision does not differ from the Cracow version with its explicit regulation concerning the validity of a married woman's deathbed gifts of property. ${ }^{130}$ For Szczerbic, it is the natural consequence of the traditional law of coverture, that is, by marriage, a woman comes under the protection and guardianship of her husband, ${ }^{131}$ does not have a separate legal existence, and cannot dispose of property without her husband's consent. Originally, the

\footnotetext{
126 No. 107.

127 No. 146.

128 No. 147.

129 No. 46. The provision is expanded in MS Q II 157 (1), No. 47.

$130 \quad J I M$, Article LXV and SzIM, Article LXV.2.

131 SzIM, Article LXV.1 This explanatory passage carries an annotation by Paweł Szczerbic, who notes that it can be found exclusively in the German-language sources.
} 
Magdeburg Law had little to say about the modalities of testamentary disposition: it just recognized the deathbed gift under the formula 'in the anticipation of death' (donatio post obitum). ${ }^{132}$ It was not until the 14th century that Poland's towns began to work on the clarification of this concept. In Cracow, the first regulations concerning testamentary disposition date back to 1342. It became the subject of a string of urban statutes (wilkierze), issued until the late 16th century. ${ }^{133}$ Clearly, in this field the Weichbild could hardly satisfy the needs and expectations of burghers wishing to dispose of their property within an unambiguous legal framework.

\subsection{Escheat}

The Weichbild addresses the problem of escheat (ius caducum) in just one article. The Sandomierz version states laconically that the property of the intestate is to be forfeited to the king. In Łaski's Statutes, which on this point follows the Cracow version and its German base, this regulation is expanded upon. The editorial modification does not affect the substance of the provision; it merely sets a time frame - a year and a day - for the prospective heirs to come forward with their claims. The phrase 'a year and a day' (annus et dies) is also to be found in the gloss of the Żegota Pauli's ms and the Leipzig Ms. The Przemyśl Ms goes even further by stipulating that the one year and a day limitation is to be suspended once the forfeiture is challenged. An identical clause appears in the gloss of the Działyńscy Codex I. The limitation clause also features in the print editions of the vulgate; in Paweł Szczerbic's text, the time span is even extended to one year and six weeks. ${ }^{134}$ It is worth noting that other provisions of the Weichbild explain that the annus et dies period was exactly a year and six weeks. ${ }^{135}$ Moreover, Article 80 of Book III of the Sachsenspiegel,

132 Friedrich Ebel, "Das spreke wy vor eyn recht ... Versuch über das Recht der Magdeburger Schoppen", in: Friedrich Ebel, Unseren fruntlichen grus zuvor: Deutsches Recht des Mittelalters in mittel- und osteuropäischen Raum. Kleine Schriften, eds. Andreas Fijal, Hans-Jörg Leuchte and Hans-Jochen Schiewer (Köln [u.a.], 2004), pp. 477-478. Cf. Adrian Schmidt-Recla, Kalte oder warme Hand? Verfügungen von Todes wegen in mittelalterlichen Referenzrechtsquelle, Forschungen zur deutschen Rechtsgeschichte, 29 (Köln, 2011), pp. $84-88,421,426$.

133 Maciej Mikuła, "Statuty prawa spadkowego w miastach polskich prawa magdeburskiego (do końca XVI wieku)" [Inheritance Statutes in Polish Towns under Magdeburg Law (until the End of the 16th Century)], Z Dziejów Prawa 7 (15) (2014), 33-63. Cf. also Krystyna Bukowska-Gorgoni, "Das sächsisch-magdeburgische Recht und die vermogensrechtlichen Verhaltnisse in den polnischen Stadten der Renaissance", in: Studien zur Geschichte des sächsich-magdeburgischen Rechts in Deutschland und Polen, eds. Dietmar Willoweit and Winfried Schich, Rechtshistorische Reihe 10 (Frankfurt am Main, 1980), p. 37.

134 SzIM, Article LIX.1.

135 Cf. Stephan Dusil, Jahr und Tag in: Handwörterbuch zur Deutschen Rechtsgeschichte, 2nd ed., 2 (Berlin, 2011), col. 1348-135o. 
which Mikołaj Jaskier referenced, has more rules concerning the treatment of an intestate estate of a peasant with his own farm. Land in excess of 30 tans (Hufe) is to escheat to the crown; medium sized farms of between 30 and 3 tans are to revert to the local feudal lord; and smaller farms are to be taken over by the sottys (scultetus). The same regulations can be found in Jaskier's Weichbild gloss with a direct reference to the aforementioned Article 80 of the Sachsenspiegel. ${ }^{136}$ This regulation had no practical significance in so far as in 16th-century Poland, land was either owned by the landlords or by the crown, and thus there was no room for crossover succession arrangements. Royal towns were the only place where the Weichbild escheat rule held water. Yet, as the research of Zygfryd Rymaszewski shows, the realization of escheats by the royal chancery in a town as prosperous as Gdańsk was extremely difficult. ${ }^{137}$

\subsection{Liability for the Decedent's Debts}

As mentioned earlier in the discussion of the Polish dower (wiano), the payment of debts is given priority over other obligations if the dower has been assigned in cash. A fairly long addition in the Statutes, following the Cracow version, lays down the rule that debts left by the heirs' father are to be paid from the decedent's estate, ${ }^{138}$ that is, if there are not enough assets in the estate to cover all the liabilities, the heirs are under no obligation to make up the difference. If the heirs refuse to settle the debts, the estate can be seized and sold to pay off the creditors. In MS BN 3068, the text was altered. There, the debitum seems to mean more than a sum of money due by an express contract; it is rather a claim or obligation whose recognition the claimant has to enforce on the heir through court action. Like most manuscripts, the Statutes says that the requisite compurgation procedure can go ahead with just three witnesses - a notable change from the Gniezno manuscript, where it was seven. ${ }^{139}$

\subsection{Summary: Pressing Needs, Numerous Alterations}

The alterations and amplifications discussed above had three main functions. First, they offered a clarification of practical difficulties of interpretation. For example, if the dower, which provided the widow with a means of support

\footnotetext{
136 JIM, Article LIX glo., col. 46; and SzIM, Article LIX.6 glo.

137 Zygfryd Rymaszewski, "Kłopoty Gdańska z kadukami królewskimi” [Gdańsk’s Problems with Royal Escheats], in: Historia integra. Studia z historii państwa i prawa, dziejów kultury, religii i oświaty epoki nowożytnej. Księga pamiątkowa ofiarowana Prof. Stanisławowi Salmonowiczowi w siedemdziesięciolecie urodzin [Historia integra: A Festschrift in Honour of Professor Stanisław Salmonowicz on His 7oth Birthday], eds. Danuta Janicka and Ryszard Łaszewski (Toruń, 2001).

138 No. 217 .

139 No. 216.
} 
upon the death of her husband, was in the form of cash, the payment of the debts due from the deceased husbands came first. Second, some regulations were made more flexible. Thus, for example, until the time of full majority, the heir could neither sell or dispose of his property, nor could he appear in court. Yet, this rule was relaxed in the Cracow version, and later by taski's Statutes, to allow some qualified legal rights to minors from the age of 12 . Third, some modifications in the laws of succession tended to rebalance them in favour of natural heirs (the close family) as against the claims of collateral heirs. Changes in the law of escheat also gave more scope for the family interest. All these alterations of the text of the Weichbild or additions to it from the Magdeburg ortyle amounted to little more than modest modifications of the traditional legal code; the carriers of more fundamental revisions were the wilkierze, municipal laws introduced by or on behalf of the town owners.

\section{5}

\section{Debtor and Creditor}

\subsection{Debt Claim and Recovery}

In addition to monetary debt, the Weichbild distinguishes various types of debt in kind (e.g. food or horses). Sometimes it makes use of no other term than debitum as an equivalent of German 'Schuld'. Yet the purpose of the substitution of 'money' (pecunia) for debitum in Article 86 concerned with inheritance debts (following the Żagań Ms) ${ }^{140}$ is not clear. ${ }^{141}$

The Statutes follows the example of the manuscripts of the Cracow version in introducing a separate article on complaints about the provision of food and drinks. It sets down the rule that the party that claims to be the owner of the products has the burden of proof. ${ }^{142}$ This formula is restated later in another article. ${ }^{143}$

In his analysis of the Statutes, Stanisław Estreicher notes that the additional provision about the liability of a buyer of a stolen horse was borrowed from the Chełmno Law. He argues that the recognition of a horse sale transacted in an inn (with a feast - litkup) is characteristic of Polish law, whereas German law insists that a disputed transaction must be decided by the court. ${ }^{144}$ This argu-

140 No. 185. A more precise formulation in Article 92 that 'debt' means a monetary debt appears in the Działyńscy Codex I and the Warsaw ms (No. 178).

141 In connection with the use of terms 'debt' / 'money', it may be noted that Article 76 declares 'debts or money' in incurred by gambling unenforceable. The word 'debts' is omitted in MS Q II 157 (1), the Przemyśl MS and the Marcin Zabowski's MS (No. 168).

$142 \quad$ No. 61.

143 No. 172.

144 Cf. Introduction, Note 17. 
ment cannot be accepted without a minor correction. The additional provision is by no means new; it is an article which was already part of the Weichbild, as indicated earlier (1.2). ${ }^{145}$ Estreicher is right when he notes the adoption by the Weichbild of the testimony of witnesses of the transaction (litkupnicy, or iudices mericipotum) as evidence of a purchase in good faith. However, the claim that it constitutes an abandonment of the general principle of alienation by municipal tribunals lacks precision and needs to be checked against actual practice. Originally, under Magdeburg Law, the type of alienation with which the courts (Auflassung) were preoccupied were property transfers. ${ }^{146}$ Gradually, the conveyances became more complex because of the multiplication of rights and encumbrances. At the same time, alienations of movables were a rarity in municipal records. It would be unrealistic to see in this proportion a reflection of what things are like in the real world, where trade in movables is at all times incomparably greater than transfers of immovables. In the case at hand, we may assume that, for example, in Zgorzelec (Görlitz) in the early 14 th century the sale of a horse was a fairly simple business transaction unaffected by legal formalities in front of the bench jury. This is not to deny that the scope of cognition of the urban authorities was evolving and enlarging, yet it could also involve the recognition of litkup, a custom mentioned in the rulings of the High Court of German Law at Wawel in Cracow as early as $1457 \cdot{ }^{147}$

In our discussion of the criminal procedure, we have noted the change in the minimum number of compurgators. A similar process seems to have been taking place in actions for the recovery of debt. The Gniezno Ms and its close affiliate, the Działyńscy Codex I, require the presence of six oath-takers to establish proof, while all the other manuscripts follow the German base in finding the testimony of two fully sufficient. ${ }^{148}$ The Statutes adopted a formula that is more favourable for the defendant, carefully editing out annotations

\footnotetext{
145 No. 16o. For individual variations in the procedure for establishing the horse's owner, see No. 183 and 184 .

146 Rudolph Sohm, "Zur Geschichte der Auflassung”, in: Festgabe zum Doctor-Jubiläum des Herrn Geheimen Justizrathes Professors Dr. Heinrich Thöl (Strassburg, 1879), pp. 112-118; Herbert Zander, Das Rote Buch der Stadt Gorlitz 1305-1416 (Leipzig, 1929), p. 27; and Werner Ogris, "Auflassung", in: Handwörterbuch zur deutschen Rechtsgeschichte, 1st ed., 1 (1971), col. $341-342$.

147 Decreta I, No. 88.

Najstarsza zgorzelecka ksiega miejska 1305-1416 (1423). Edycja i komentarz [The Earliest Book of Municipal Court Records of Zgorzelec (Görlitz) 1305-1416 (1423): A Critical Edition and Commentary], 1, eds. Krzysztof Fokt, Christian Speer, Maciej Mikuła, Fontes Iuris Polonici 5 (Kraków, 2017), No. 112, 557.

148 No. 175 and 216.
} 
from other manuscripts that specify the number of oath-takers. ${ }^{149}$ At another point it, made into law the broad definition of debt repayment from the Żagan Ms, namely, that the debt can be paid in such denarii (i.e. coins, or simply money) that are used in the court that hears the case (i.e. that are in circulation in that area). ${ }^{150}$

In addition to obligations arising from contracts, the Weichbild addresses the issue of obligations in tort. Article 77 sets down the liability for damage to property deposited for safe-keeping or pledged as collateral. ${ }^{151}$ To obtain release from liability, the keeper must prove that the damage occurred through no fault of his own. If he succeeds and the collateral was an animal that died, the creditor shall lose his pledge. This provision was taken over from Sachsenspiegel by Konrad of Sandomierz before being incorporated into the Statutes. ${ }^{152}$ Therefore, in this case, too, the Statutes does not come up with a formula that is new or original.

The security for debt is the subject of Article 64 of the Weichbild. Its provisions were passed on to the Statutes via the Cracow version without any notable alteration. Yet a most pertinent extension from the Gniezno Ms that all heirs, not just his children, did not succeed to the security for debt of their deceased father was available to the authors of the Statutes. ${ }^{153}$ Whether they chose to ignore it or just missed it is a question of some interest, albeit probably unresolvable.

\subsection{The Guest as Debtor and Creditor}

The early texts of the Weichbild provide for common-sense exceptions from general rules if one of the litigants is an alien. The problem of defining who may qualify as alien/guest (hospes) is discussed above in Section 2.3. The definition is dictated by practical considerations. As he has to go back home to collect the money he owes in debt, the alien should be given an extension of the payment deadline. Two additions in the Cracow version and the Statutes also deal with the question of pledges that guarantee the payment of a debt. The

149 No. $96,152,177$, and 186 . For alterations in the provision concerning the suspension of legal proceedings against a person setting off on a long journey (business, pilgrimage), see No. 52 , 53, and 54. For adjustments within the provisions concerning the enforcement of debt payment in the Tomasz of Bydgoszcz's ms, see No. 176; and a revision of the regulations concerning pledge and wergild in MS Q II 157 (2) and the Mikołaj of Smogorzewo's MS, see No. 194 .

150 No. 181.

151 No. 173 .

$15^{2}$ The problem of damage caused by animals is addressed in an addition in the Przemyśl MS, see No. 218.

153 No. 151. 
court should accept a guest (i.e. a person) as security for debt. ${ }^{154}$ Another rule or recommendation, which also derives from the ortyle, says that objects must not accepted as pledge. If, however, this type of arrangement between parties (when one of them was a guest) did take place, general rules apply, except where the contract makes an exemption. ${ }^{155}$

\subsection{The Servant as Debtor and Creditor}

Following the text of the Sandomierz version, the Statutes reaffirms the general principle that the master cannot be held responsible for his servant's goods, as the latter was free to dispose of them as he chose. ${ }^{156}$ There was, however, one exception to this rule: the master was liable to his servant in a situation when the latter's horse was stolen. ${ }^{157}$ As the Częstochowa ms and the Kielce Ms explain, the liability extends to all assets that are essential for the servant's livelihood as it is the master's duty to maintain his servant. ${ }^{158}$ At the same time, the law solemnly declares that all transactions (especially bets) made a by servant which involve the loss, damage, or sale of his master's property are invalid. Those additions come from the Sachsenspiegel, but they can also be found in other texts, such as the Chełmno Law. Thus, Konrad of Sandomierz's decision to include them in his Weichbild compilation was no innovation. Nonetheless, the author of Statutes chose drop the procedural formula (found in some texts of both the Sandomierz and the Cracow version) which made the master's suit against his servant dependent solely on the testimony of oath-helpers. This is understandable, as by that time the courts were accustomed to relying on other forms of obtaining proof (i.e. by examining documents). ${ }^{159}$

\subsection{Summary: Liability Made More Precise}

Changes and augmentations concerning liability for debt were aimed first of all at increasing the precision of individual provisions. The Statutes, for example, explicitly stated what money was to be used to pay the debt. Some rules were amended to make them more coherent: for example, the exemption of children from the pledges of their deceased father was to apply to relatives, as well. Clarifications and additional regulations were introduced into provisions concerning liability for damage to leased property or to property pledged as collateral. Finally, the Statutes opened up other forms of obtaining proof,

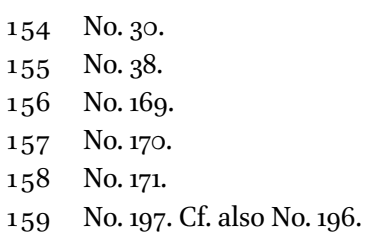


which were more appropriate in the changing times, in cases of debt as an alternative to the traditional oath-swearing. These changes show that adaptation for practical use was a major factor in the evolution of the Weichbild.

A textual comparison of the earliest extant German Weichbild with the Weichbild in Łaski's Statutes shows the effect of the evolution of the Ius Municipale Magdeburgense over more than two hundred years. The material covered in this analysis includes Latin translations of numerous German texts in the Sandomierz and Cracow versions, provisions carried over from the ortyle and the Sachsenspiegel, adaptations (during the translation phase) of the Saxon-Magdeburg Law to the requirements of its Polish users, and other alterations (both in substance and in form). The authors of the Statutes had at their disposal at least two Latin texts of both versions, but, we may assume, they did not see all of the Weichbild manuscripts that were produced over that period. Their product - the Statutes - is a thoughtful and carefully executed synthesis of the Sandomierz and Cracow versions and can unreservedly be described as a legal text that is both complete and authoritative.

The Statutes' redaction of the Weichbild did not bring substantial changes to the texts widely used in legal practice. Nor was the incorporation of ortyle judgments of the Magdeburg Bench - from the Cracow version into the new, authorized book of laws in any way dramatic. After all, they had been a legitimate source of law before. A series of alterations, discussed in detail in Section 1.1, are hardly far-reaching enough to justify the opinion that the publication of the Weichbild in the Statutes constituted a reform of Poland's urban law. However, the impact of the printing of the Statutes cannot be overestimated. Lawyers and courts all over Poland received a uniform text of the law, more comprehensive and reliable than any of its versions handed down in Latin manuscripts, furnished with a vast network of references to Polish land law and the Sachsenspiegel.

We know of no manuscript of Saxon-Magdeburg Law with the Weichbild as its sole source. Consequently, the study of the textual evolution of the Weichbild cannot ignore other sources of that law, especially the Sachsenspiegel and the Magdeburg ortyle, which make up each of the extant texts in varying degrees. In other words, in practice, the modification of the text of the Weichbild in any individual manuscript depends on the positioning of its companion texts. This is not much of a problem in a manuscript where the Weichbild pruned 
some articles from the Sachsenspiegel, but the latter is part of it, all written in a single hand. Then there is the Żegota Pauli's ms without the Sachsenspiegel, an arrangement which makes the additional provisions and alterations in its Weichbild so much more important for the legal practice. Of even greater importance are the ortyle, which, in the Cracow version, became part of the text of the Weichbild, and which were ultimately blended into the Statutes in a manner which preserved none of their distinctive origin. Yet the fact that so many legal formulas from the ortyle were adopted by the Statutes, the official code of law, proves their worth and significance. What should also be borne in mind is the fact that - notwithstanding the amendations and the collation of the Sandomierz and Cracow versions - the text in the Statutes does not constitute a new translation or version of the Weichbild. It is the most comprehensive revised version of the Silesian-Małopolska compilation of the Weichbild. Although it became the authorized version, it was by no means the last one to be made and circulated. The replacement of the old manuscripts by a uniform text in print took years. In the meantime, new manuscripts of the Weichbild were produced, including copies of the extant Gniezno MS (MS BOz) and Commune incliti (MS BN 3068). The continued use of the manuscripts may have been caused by the inadequate number of the printed copies of the Statutes, as well as the persistence of old habits and the difficulty of accepting the formula that the text of the Statutes was sacrosanct. Tomasz of Bydgoszcz, the copyist of MS BN 3068, certainly represents the old mind-set. His work is not a verbatim copy of the Statutes, but a compilation, thick with alterations of all kinds.

The changes in text of the Weichbild in diverse manuscripts and in the Commune incliti, which brought to an end the medieval history of that legal text, indicate that its evolution was driven by its functional uses. These functions can be identified as follows: 1) concern for the realities of Polish towns which resulted in the introduction of Polish terminology; 2) concern for precision shown in the introduction of legal definitions; 3) elimination of ambiguity and uncertainty; 4) the need for legal practitioners to have a legal text that would take into account the clarifications of the Magdeburg judgments (ortyle); and 5) the need to adapt the legal formulas of the Weichbild to the realities of urban life in late medieval Poland. While the evolution of the Weichbild was marked by piecemeal adaptation rather radical breaks, the common denominator of the all changes was adapting the text of the Magdeburg Law for judicial practice in a new environment. Its wide practical use is attested by numerous hand-written notes in the margins of all copies of the Weichbild, in the medieval manuscripts, and in the incunabula of the Commune incliti. Those annotations are discussed in the following chapter. 


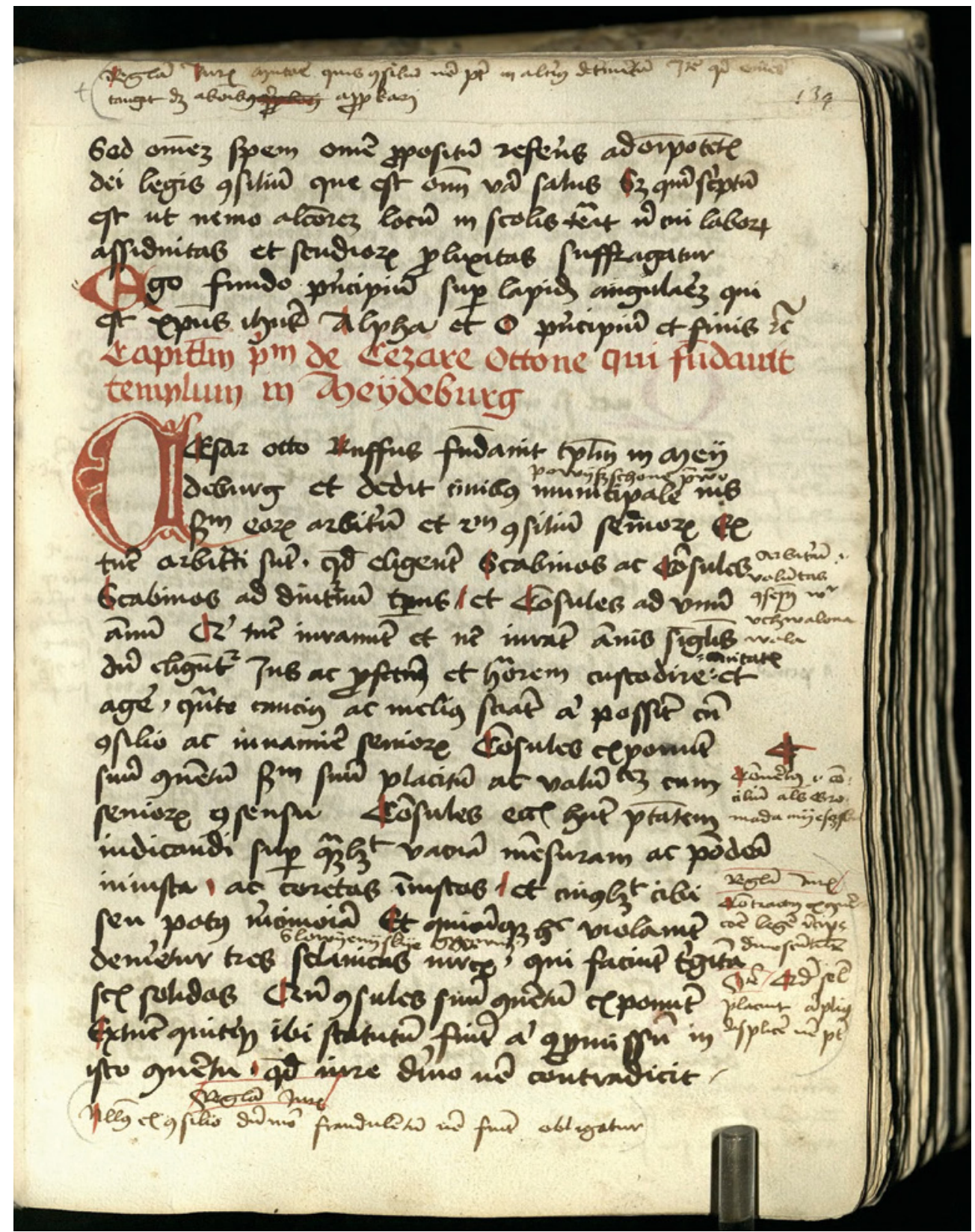

рното 7 Działyńscy Codex I, The Kórnik Library of the Polish Academy of Sciences, Shelfmark 8o1, f. $139 \mathrm{~V}$ 


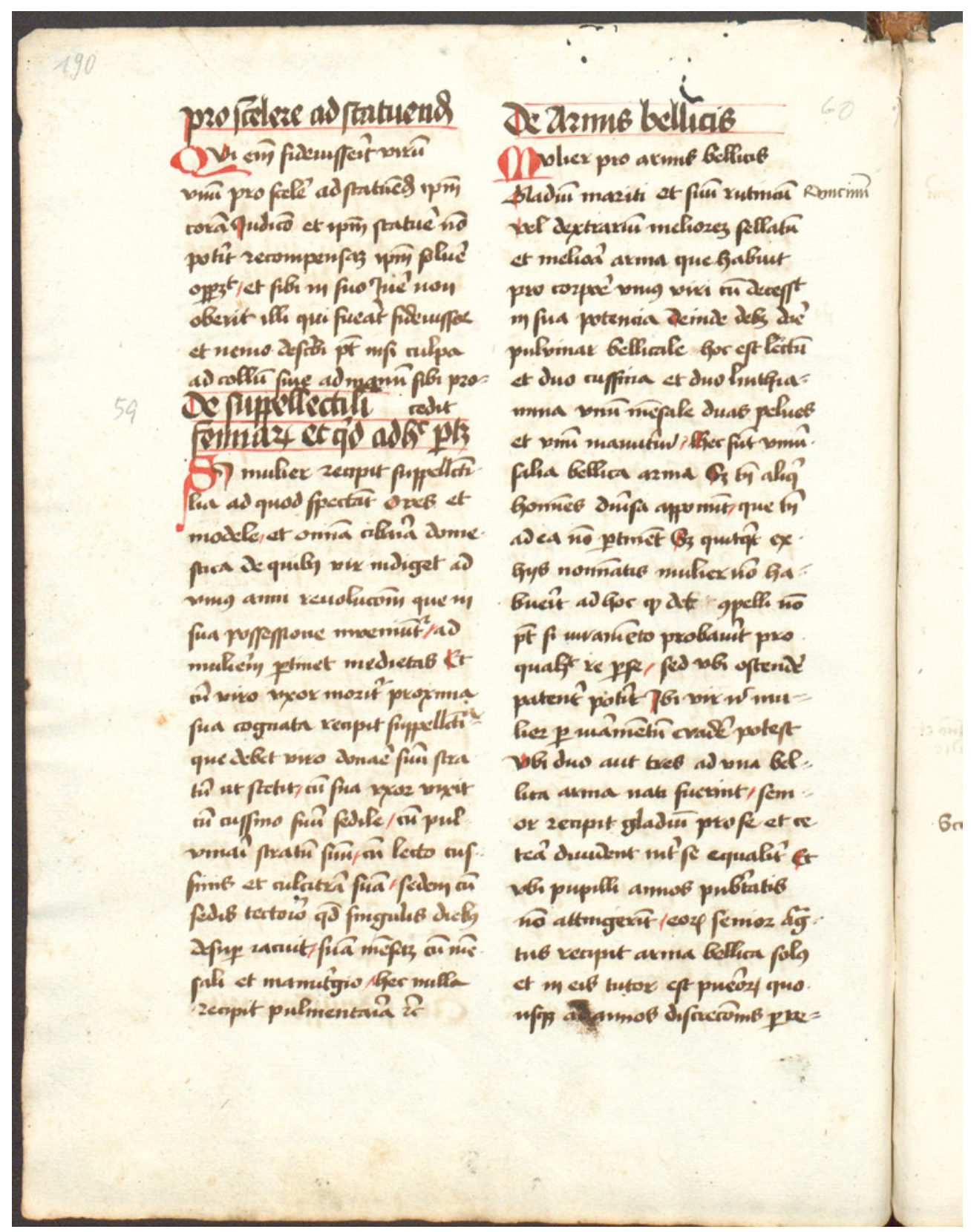

рното 8 Żegota Pauli's manuscript, Jagiellonian Library in Cracow, Shelfmark 4405, f. $100 v$ 